\title{
Geomorphic analysis of the Central Range fault, the second major active structure of the Longitudinal Valley suture, eastern Taiwan
}

\author{
J. Bruce H. Shyu ${ }^{\dagger}$ \\ Kerry Sieh \\ 91125, USA \\ Yue-Gau Chen \\ Ling-Ho Chung \\ Department of Geosciences, National Taiwan University, Taipei, Taiwan
}

Tectonics Observatory, Division of Geological and Planetary Sciences, California Institute of Technology, Pasadena, California

\section{ABSTRACT}

Numerous landforms along the Longitudinal Valley suture of eastern Taiwan indicate that two opposing reverse faults currently dominate the suturing process between the Luzon volcanic arc and the Central Range of Taiwan. The east-dipping Longitudinal Valley fault, on the eastern flank of the valley, is well known. The west-dipping Central Range reverse fault, on the western flank of the valley, is more obscure. Nonetheless, it has produced many uplifted lateritic fluvial terraces along the eastern flank of the Central Range in the central reach of the valley, from just north of the Wuhe Tableland to near Chihshang. The fault appears to be active but blind south of Chihshang and inactive along the northern part of the Longitudinal Valley. The late Quaternary slip rate of the fault is less than $12.8 \mathrm{~mm} / \mathrm{yr}$. This constraint means that the fault is absorbing far less than half of the horizontal shortening across the Longitudinal Valley suture. However, the late Quaternary slip rate along the fault may be comparable to the uplift and exhumation rate of the Central Range. This suggests that localized brittle slip along the Central Range fault is an important component of crustal thickening and uplift of the range, even though additional shortening and crustal thickening may be occurring because of pervasive deformation beneath the range.

Keywords: Taiwan, tectonic geomorphology, Central Range fault, Longitudinal Valley, sutures, exhumation.

†E-mail: jbhs@gps.caltech.edu.

\section{INTRODUCTION}

The island of Taiwan is the product of the collision of the Eurasian and the Philippine Sea plates over the past several million years (e.g., Ho, 1986; Teng, 1987, 1990, 1996, and references therein; Fig. 1). The Longitudinal Valley of eastern Taiwan has long been known as one of the world's most tectonically active belts. It is the suture between the colliding Luzon volcanic arc and the Central Range, the mountainous backbone of Taiwan. Seismic activity and active structures are abundant along this linear, $\mathrm{N}-\mathrm{S}$-trending valley.

The principal active structure in the valley is the Longitudinal Valley fault (e.g., Shyu et al., 2005a; Fig. 2). This east-dipping, oblique-slip fault, which runs along the eastern edge of the valley, is slipping at a high rate and creating rapid uplift of the Coastal Range in its hanging-wall block (e.g., Yu and Liu, 1989; Hsu et al., 2003; Shyu et al., 2006a). This high rate of activity has inspired numerous geodetic (e.g., Yu and Liu, 1989; Liu and Yu, 1990; Angelier et al., 1997; Lee et al., 2001, 2003; Yu and Kuo, 2001) and seismologic (e.g., Cheng et al., 1996; Chen and Rau, 2002; Kuochen et al., 2004; Lin, 2004) investigations. These studies have shown that one part of the Longitudinal Valley fault is creeping aseismically at a high rate, but is also capable of coseismic rupture. Ruptures of the fault produced large earthquakes in 1951 and many moderate earthquakes subsequently, including those in 1972, 1995, and 2003 (Chan, 1985; Chen and Rau, 2002; Lin, 2004; Kuochen et al., 2004, 2006). Aftershocks of these moderate earthquakes appear to illuminate the fault plane as a listric surface (Chen and Rau, 2002; Kuochen et al., 2004).

Although much is known and accepted about the activity of the Longitudinal Valley fault, a related structure on the western edge of the valley remains very controversial. Many believe that a west-dipping reverse fault is present along the western edge of the valley, making the valley a "ramp valley" flanked by reverse faults. Biq (1965) named this east-vergent reverse fault the Central Range thrust. However, some believe there is, instead, a normal fault, which accommodates subsidence of the Longitudinal Valley floor with respect to the Central Range (e.g., Crespi et al., 1996; Lee et al., 2001, 2003). Extending the spectrum of opinion, others maintain that there is no fault at all, and that the eastern flank of the Central Range is being covered by the sediments of the valley (e.g., Malavieille et al., 2002).

This is an important debate, because the nature of the Central Range fault has significant implications for understanding uplift and exhumation of the range. Many view the Taiwan orogen as a simple one-sided wedge, with an east-dipping throughgoing basal detachment (e.g., Suppe, 1981; Davis et al., 1983; Carena et al., 2002). However, this model has difficulty explaining the observation of rapid exhumation of eastern Central Range rocks (e.g., Jahn et al., 1986; Liu et al., 2001; Willett et al., 2003). A west-dipping retro-shear zone on the eastern flank of the range could help explain uplift of the Central Range and exhumation of metamorphic rocks of eastern Taiwan (e.g., Willett et al., 1993, 2003; Willett and Brandon, 2002).

Furthermore, the Longitudinal Valley is one of the very few locations on Earth where suturing is actively occurring. A better understanding of this suture will undoubtedly enhance the knowledge of sutures in general. Whereas we know much about the Longitudinal Valley fault, on the eastern flank of this suture, much less is known about the western side of the suture. Is 

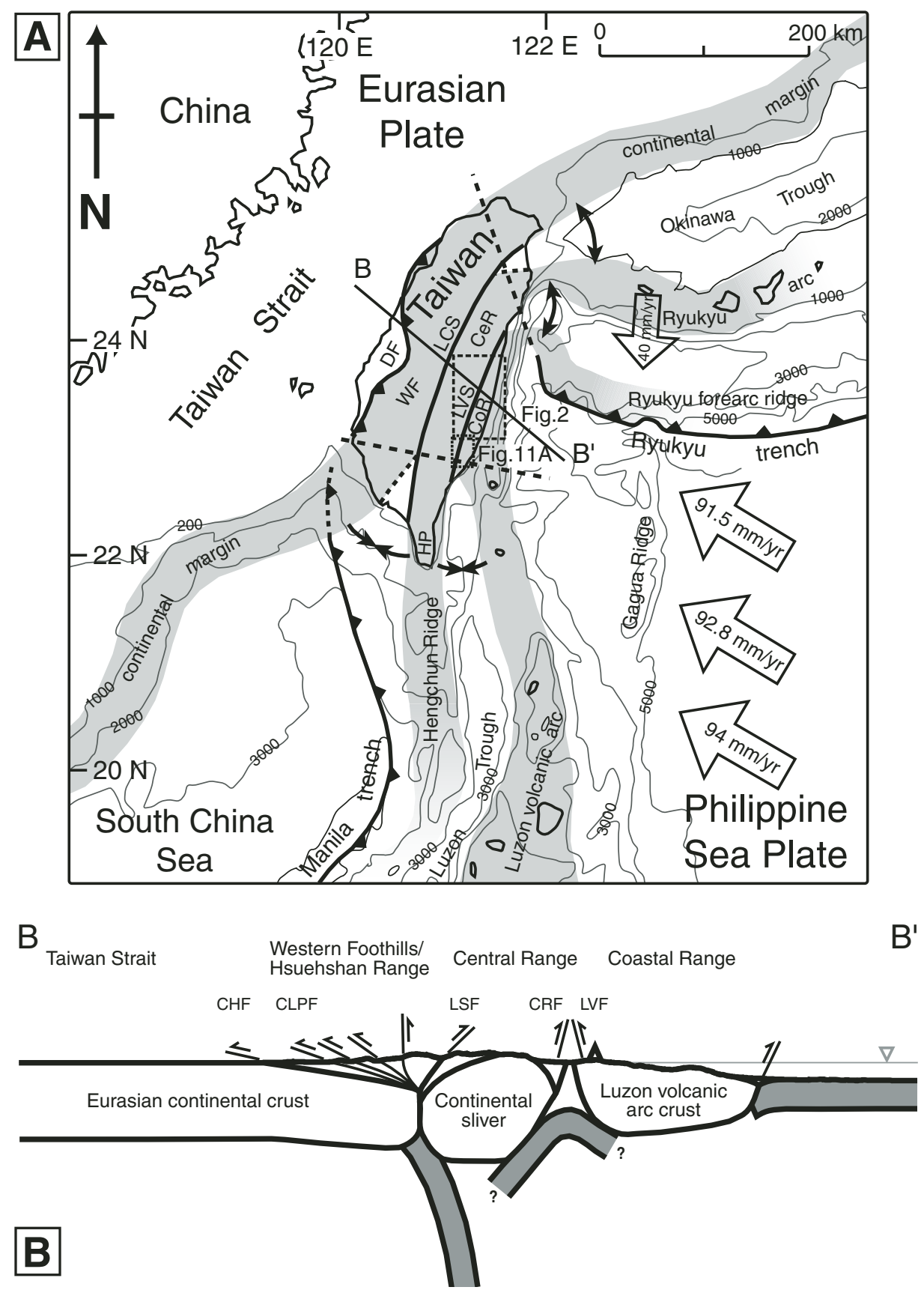

Figure 1. (A) Map of Taiwan and surrounding region, showing the tandem suturing of the Luzon volcanic arc and a sliver of continental crust to the Chinese continental margin. In eastern Taiwan, the Longitudinal Valley suture (LVS) is the eastern of the two sutures. This suture joins the Coastal Range (CoR), the docked part of the Luzon volcanic arc, and the continental sliver of the Central Range (CeR), the mountainous backbone of the island. Current velocity vectors of the Philippine Sea plate relative to South China, at $124^{\circ} \mathrm{E}$ and $20^{\circ}, 21^{\circ}$, and $22^{\circ} \mathrm{N}$, are calculated using the Recent plate velocity model (REVEL) of Sella et al. (2002). Current velocity vector of the Ryukyu arc is adapted from Lallemand and Liu (1998). Black dashed lines are the northern and western limits of the Wadati-Benioff zone of the two subduction zones, taken from the seismicity database of the Central Weather Bureau, Taiwan. DF-deformation front; LCS_Lishan-Chaochou suture; WF-western foothills; HP-Hengchun Peninsula. (B) A schematic crustal cross section across central Taiwan, along line B-B' in (A), showing relationship of the three terranes during suturing. $\mathrm{CHF}$ - Changhua fault; CLPF-Chelungpu fault; LSF_Lishan fault; CRF_Central Range fault; LVF_-Longitudinal Valley fault. No vertical exaggeration. (Parts A and B of this figure are adapted from Shyu et al., 2005b) there an active structure on the western side of the Longitudinal Valley suture as well? That is, is there a Central Range fault that has a slip rate and structural history comparable to the Longitudinal Valley fault? Answers to these questions are important not only in quantifying the seismic hazard of eastern Taiwan and understanding the tectonic kinematics and evolution of the island, but also in improving the general understanding of suturing processes.

Previous work on the western flank of the Longitudinal Valley suture has focused on structural, petrologic, and geochronologic analyses of the basement rocks of the Central Range (e.g., Jahn et al., 1986; Lo and Onstott, 1995; Crespi et al., 1996; Liu et al., 2001; Fisher et al., 2002). Although these works have provided insight into the kinematics of the basement rocks, there has been a dearth of work on young surface processes along the western flank of the Longitudinal Valley. Detailed geomorphologic and neotectonic studies of landforms could add important constraints on the active tectonic processes of eastern Taiwan, augmenting what has been learned from studies of older rocks.

In this paper, we present a detailed geomorphic analysis of the eastern flank of the Central Range that supports the existence of a reverse fault along at least part of the western edge of the valley. Following Biq (1965), we call this structure the Central Range fault. Our principal means for geomorphic analysis include two digital elevation models (DEM), one with a $40 \mathrm{~m}$ resolution and the other with a $5 \mathrm{~m}$ resolution, followed by mapping and investigation of fluvial landforms in the field. Also, we have augmented our geomorphic analysis with published information from geodetic and seismologic analyses.

\section{GEOLOGIC SETTING}

Taiwan is forming at the boundary between the Philippine Sea plate and the South China block of the Eurasian plate. South of Taiwan, the two blocks are converging at $\sim 90 \mathrm{~mm} / \mathrm{yr}$ (Sella et al., 2002; Shyu et al., 2006a; Fig. 1), and the convergence is being absorbed by subduction of the South China Sea along the Manila Trench. At the latitude of southern Taiwan, subduction has ceased, because oceanic lithosphere of the South China Sea has been wholly consumed, and the Chinese continental margin impinges upon the trench. Thus, the convergence gives way to collisional deformation of the continental margin, resulting in the formation of the mountainous island of Taiwan.

Recently, we offered a new point of view about this collision, based upon geomorphic analysis of active structures of the island (Shyu 
et al., 2005b). In this model, the Taiwan orogen is made more complicated by the existence of an intervening continental sliver, comprising the submarine Hengchun Ridge and the Central Range backbone of Taiwan. Because the Hengchun Ridge and the Central Range are structurally continuous, the existence of pre-Mesozoic basement rocks in the Central Range indicates that this belt, in the upper-plate side of the Manila Trench, may not be simply a sedimentary accretionary wedge but a thin continental sliver (Shyu et al., 2005b). As a result, the orogen is being formed by a tandem suturing of the Chinese continental margin, the continental sliver, and the Luzon volcanic arc (Fig. 1). In eastern Taiwan, the Longitudinal Valley suture is the eastern of the two sutures, separating the docked volcanic arc of the Coastal Range and the metamorphic core of the Central Range continental sliver.

Along the east-dipping Longitudinal Valley fault, the highly shortened volcanic rocks and forearc and intra-arc basin sediments are thrusting over the current sediments of the Longitudinal Valley, at rates up to several tens of $\mathrm{mm} / \mathrm{yr}$. From uplift rates of river terraces in the hanging-wall block of the fault, these geodetically determined rates extend back through at least the Holocene (Shyu et al., 2006a). Along one segment of the fault, many small earthquakes illuminate a listric shape of the fault plane (e.g., Kuochen et al., 2004). Seismic activity along the Central Range fault is less impressive. Thus, the existence of the fault has been controversial for many years.

The Central Range, on the hanging-wall block of the proposed Central Range fault, consists of metamorphosed sediments and basement rocks. Structural analysis indicates that the range is fundamentally an anticlinorium, with slates and other slightly metamorphosed sediments overlying a more highly metamorphosed core (e.g., Ho, 1988). The underlying basement rocks include shallow-marine sediments that contain late Paleozoic fossils (Yen et al., 1951; Yen, 1953), and Eocene to Miocene deep-marine foraminifera fossils have been recovered from the overlying slates (e.g., Chang, 1971). Thus, the range is likely the metamorphosed product of what is now the submarine Hengchun Ridge: A continental sliver, with some shallow-marine sediment, is mantled by deep-marine sediments of the forearc region.

\section{GEOMORPHIC ANALYSIS NEAR THE WUHE TABLELAND}

The most prominent landforms that lead us to suspect the existence of the Central Range fault are between the Fuyuan and Taiping Rivers,

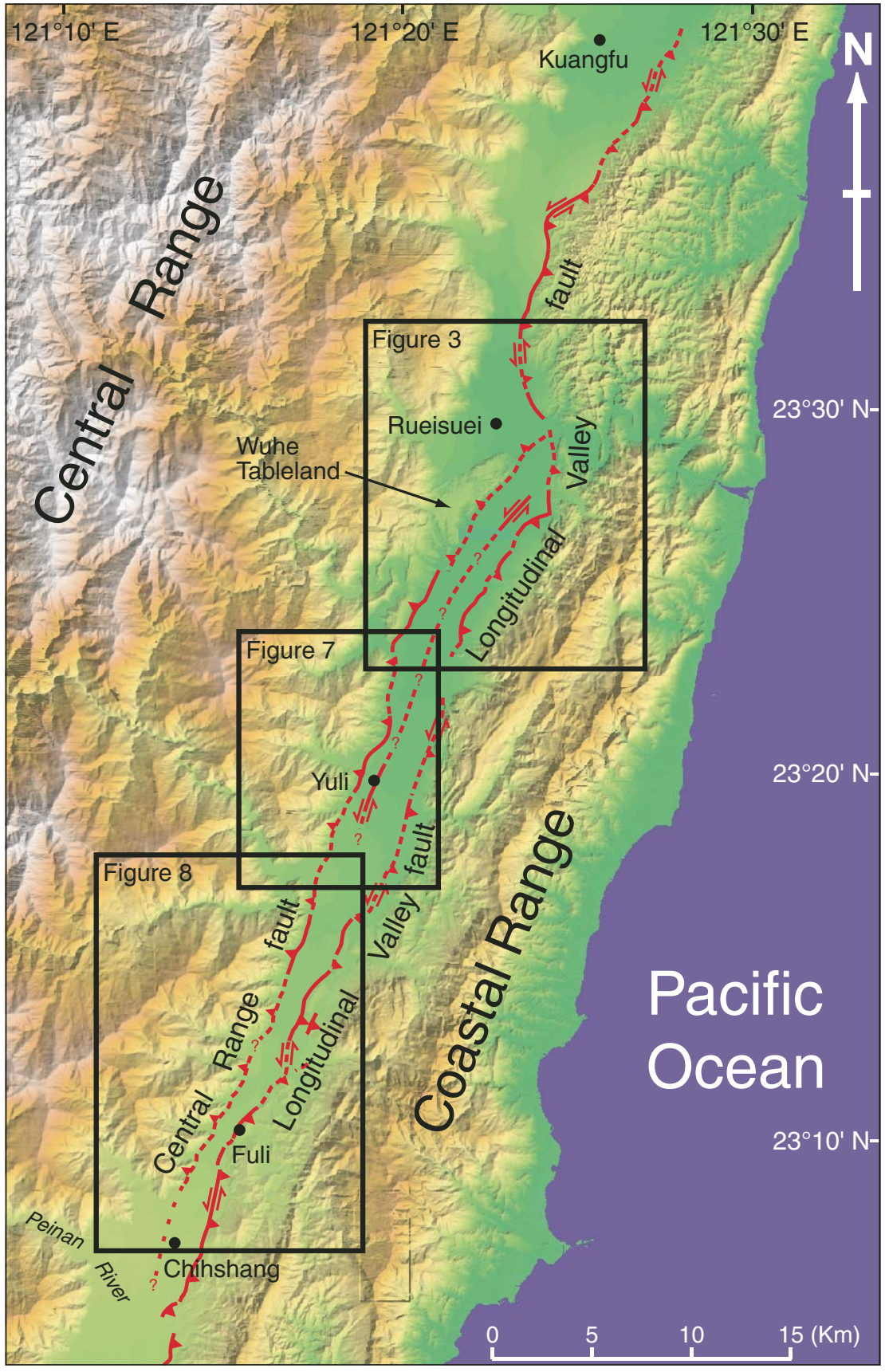

Figure 2. Map of major structures in the middle part of the Longitudinal Valley, adapted from Shyu et al. (2006b). The east-dipping Longitudinal Valley fault is an obliquely slipping reverse fault, along which the Coastal Range is rising rapidly and moving toward the Central Range. In this paper, we present geomorphic evidence for the less-prominent Central Range fault. This fault is a west-dipping reverse fault, above which many fluvial terraces and the Wuhe Tableland are rising slowly.

about halfway between the northern and southern ends of the Longitudinal Valley, near the town of Rueisuei (Figs. 2 and 3). There, rising anticlines in the hanging-wall block of the Central Range fault have produced the Wuhe Tableland in the north and a series of river terraces and a bedrock ridge in the south. The growth of these anticlines has diverted the Hungyeh River to the north and the Taiping River to the south.

The Wuhe Tableland is an uplifted fluvial terrace formed by the Hsiukuluan River, one of the largest rivers in eastern Taiwan. The tableland 


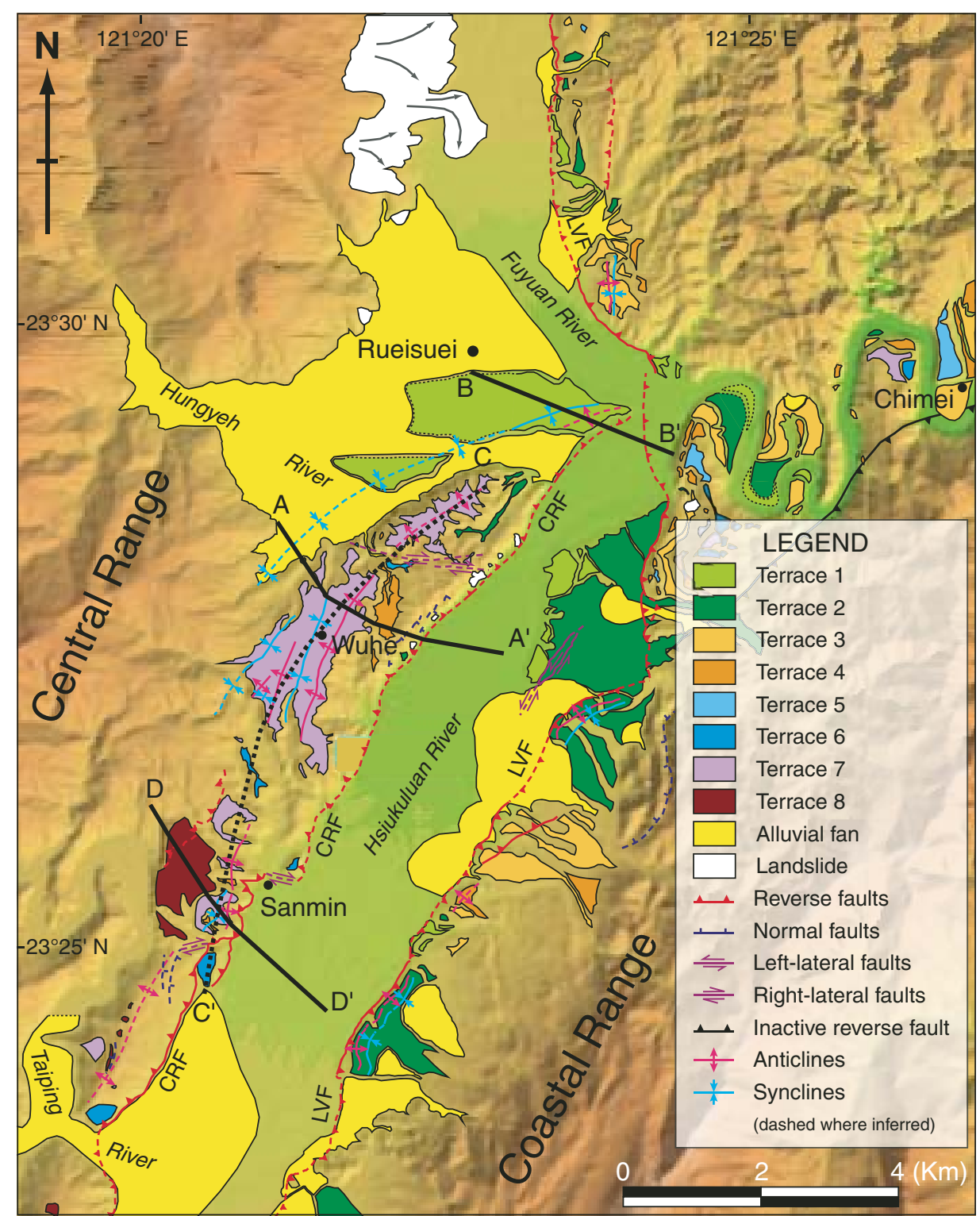

Figure 3. Detailed map of geomorphic and neotectonic features on and around the Wuhe Tableland showing deformation by young anticlines extending $13 \mathrm{~km}$ between the Fuyuan and Taiping Rivers. A syncline in young sediments flanks the anticlines on the northwest. These folds are formed in the hanging-wall block of the west-dipping Central Range fault (CRF). The Wuhe Tableland is a long, nearly continuous patch of uplifted lateritic fluvial terrace on the crest of a major anticline. Undulations on the broadly anticlinal shape of the surface of the tableland reflect the existence of secondary folds. A deformed lower and younger fluvial terrace shows that the fold extends nearly $2 \mathrm{~km}$ northeast of the tableland and may plunge beneath the Longitudinal Valley fault (LVF). Lateritic fluvial strath terraces along the eastern flank of the Central Range and a bedrock ridge show that the anticlines extend several kilometers southwest of the tableland. Fluvial terraces along the western flank of the Coastal Range, deformed by the east-dipping Longitudinal Valley fault, also appear in the figure. surface is $\sim 170 \mathrm{~m}$ above the present riverbed. Its top surface is gently warped, and its highest point is near its southern end.

About $1.5-2.5 \mathrm{~m}$ of lateritic soil caps the surface of the Wuhe Tableland. Underlying the soil are layers of gravel and sand. These fluvial deposits comprise the entire northwestern flank of the tableland along the cut bank of the Hungyeh River (Figs. 4 and 5A). In contrast, along the southeastern flank of the tableland, cut by the Hsiukuluan River, are scattered outcrops of metamorphic rocks, mostly slates, below the fluvial sediments (Fig. 5B).

The fluvial deposits consist of mostly cobbles and boulders, with rare thin layers of sand. It is of interest that the fluvial deposits on the Hungyeh River side of the tableland are very different from those on the Hsiukuluan River side. On the Hungyeh River side, matrix-supported, larger and more-angular gravel beds suggest that the sediments were deposited by the Hungyeh River (Fig. 5A). On the Hsiukuluan side, smaller, more-rounded and clast-supported gravels, more frequent fine-grained layers, and even rare mud layers with tree trunks suggest that the sediments formed in the much larger and wider Hsiukuluan River and its marginal slack-water environments (Figs. 5C and 5D). Therefore, there appears to be a sedimentary boundary between facies of the two rivers beneath the surficial lateritic soil of the tableland.

The age of the tableland is poorly constrained. The overlying lateritic soil implies that the surface formed at least a couple tens of thousands of years ago, judging from the dates of similar lateritic terraces in other parts of Taiwan (e.g., Chen, 1988). The tree trunks found within the fluvial sediments of the tableland are older than the 50 k.y. limit to ${ }^{14} \mathrm{C}$ dating. However, there are no further constraints on the age of the tableland. Preliminary dating from optically stimulated luminescence (OSL) of the fluvial sediments suggests that the sediments may be $\sim 45 \mathrm{ka}$, but large errors limit the usefulness of these analyses (Chen et al., 2004).

The fluvial sediments of the Wuhe Tableland clearly formed in the Hsiukuluan and Hungyeh Rivers and were then uplifted along a west-dipping Central Range reverse fault. The tableland surface, once the riverbed, has risen at least $170 \mathrm{~m}$ after its formation several tens of thousands of years ago. The gently warped tableland surface has been warped into an anticline with secondary folds on the hanging-wall block of the fault (Figs. 4 and 6A). The exposed slate basement below the fluvial deposits on the eastern flank of the tableland formed at depths far below the land surface. Because the thickness of fluvial sediments in the Longitudinal Valley is greater than $1 \mathrm{~km}$ (Chen et al., 1974; Chen, 
1976), this suggests a minimum total offset of several kilometers across the fault.

In the present Hungyeh River bed, we have found an outcrop of gently tilting indurated gravels and sand (Figs. 4 and 5E). The mild induration of these sediments indicates that they are old and perhaps correlative with sediment beneath the Wuhe Tableland. The strike $\left(\mathrm{N} 82^{\circ} \mathrm{E}\right)$ and dip $\left(12^{\circ} \mathrm{NW}\right)$ of the beds suggest the presence of a syncline northwest of the tableland, north of the Hungyeh River (Figs. 3 and 4). Therefore, the northwestern side of the Wuhe Tableland has been eroded significantly by the Hungyeh River. However, because the Wuhe sediments are still uplifting and crop out in the Hungyeh River bed, the anticline and syncline appear to be active.

At the northeastern corner of the Wuhe Tableland is an outcrop of vertically bedded gravels and sand layers. These beds can be explained if, earlier in its development here, the Central Range fault was blind and these beds were part of a fault-propagation fold.

Just northeast of the tableland, a small, lower fluvial terrace provides a clear demonstration of the northeastward continuation of the Wuhe Tableland anticline, syncline, and fault (Figs. 3 and 6B). The terrace formed as part of the Hungyeh River fan near its confluence with the Longitudinal Valley. Subsequent to deposition, the fluvial surface tilted toward the northwest, rising above the surrounding youngest and active alluvial fan surface. Fluvial sediments underlying the terrace surface are also tilted (Fig. 4). The form of the terrace is an anticline-syncline pair, analogous to the topographic manifestation of the fault further to the south, on the Wuhe Tableland. The southeastern flank of the terrace is steep and may, in fact, be a fault scarp. About $3 \mathrm{~km}$ northwest of the scarp, the terrace merges smoothly with the active alluvial fan. This indicates that the age of the terrace and its deformation are very young.

Some published maps depict the Wuhe Tableland lying on the hanging-wall block of a strand of the east-dipping Longitudinal Valley fault, at the western edge of the tableland (e.g., Yu, 1997; Lin et al., 2000). However, it is clear from field relationships that on its western flank, the fluvial sediments of the tableland overlie a slate strath and that no fault is present there (Fig. 5F).

The exact location of the Central Range fault is unclear. Although we believe the fault crops out very close to the southeastern base of the Wuhe Tableland, fluvial action by the Hsiukuluan River may have eroded the tableland edge somewhat.

The landforms of the Central Range fault continue south of the Wuhe Tableland. West of the village of Sanmin, a series of fluvial terraces perches on the eastern flank of the Central

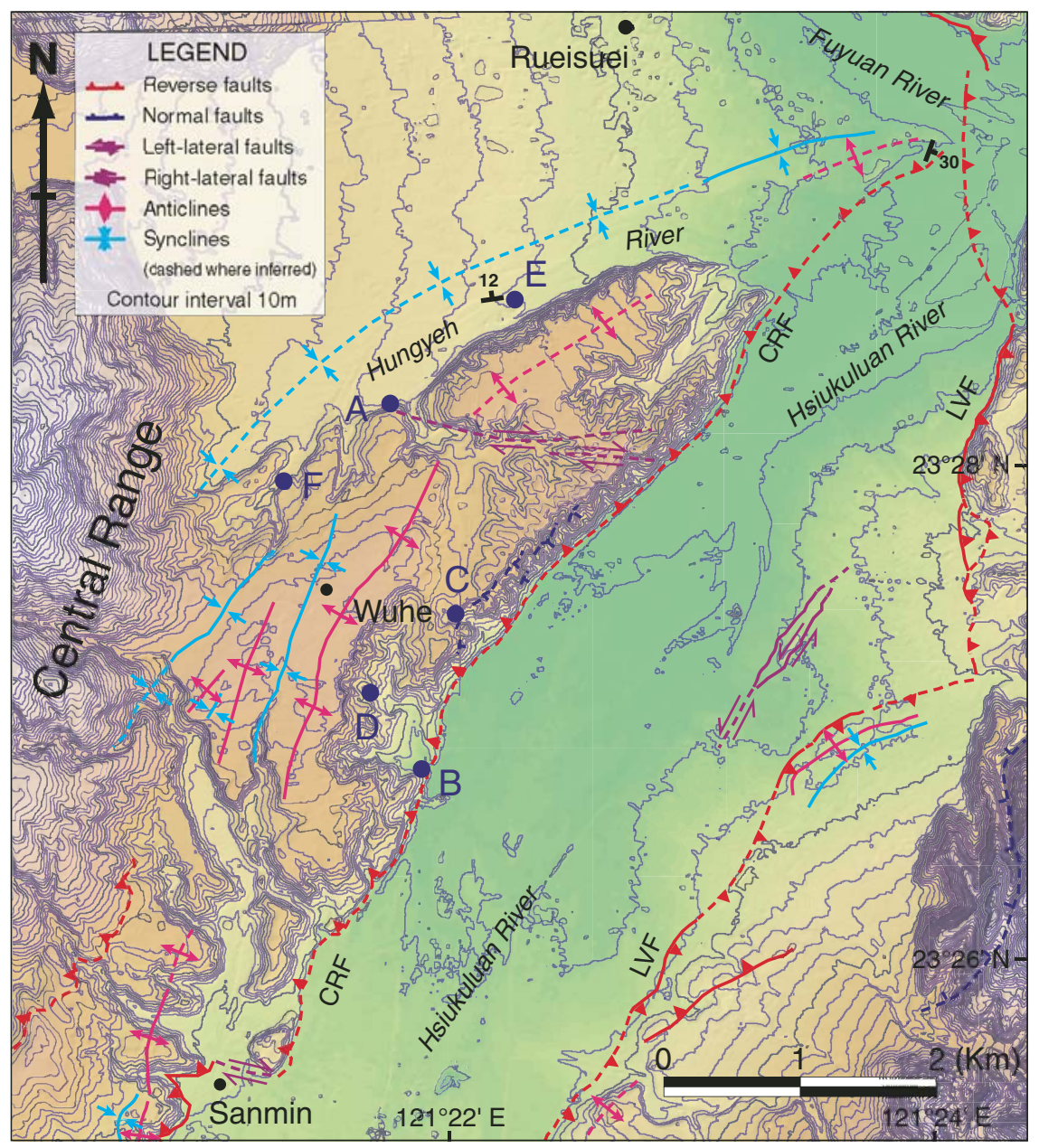

Figure 4. Index map of locations where photographs shown in Figure 5 were taken in the Wuhe Tableland area. LVF_Longitudinal Valley fault; CRF_Central Range fault.

Range, at heights up to $150 \mathrm{~m}$ above the Longitudinal Valley floor (Fig. 3). These are strath terraces that generally have fluvial gravel caps less than a meter thick. A topographic profile across both the Wuhe Tableland surface and the Sanmin terraces clearly shows that the majority of the Sanmin terraces are correlative with the Wuhe Tableland (Fig. 6C). Prominent chemical and mechanical weathering of the Sanmin terrace surface is evidenced by alteration of basement slate to reddish-colored rock fragments, consistent with the hypothesis that the Sanmin terraces are similar in age to those of the Wuhe Tableland. Lateritic soil, however, is poorly developed on top of the Sanmin terraces, probably because of the lack of thick fluvial sediments.

The fluvial terraces west of Sanmin represent the uplifted riverbed of the Hsiukuluan River. Their uplift is due to slip along the Central Range fault beneath the eastern flank of the range, because the terraces are the southward extension of the Wuhe Tableland. The fact that the terraces are strath terraces, with just a thin cap of fluvial gravel, suggests that the hangingwall block had been rising along the fault since the time of formation of the terrace. Moreover, the presence of slates beneath the thin fluvial sediment cover of the terraces clearly shows that the terrace straths had risen at least several tens of meters prior to fluvial downcutting. A small right-lateral tear may be present near Sanmin, where the fault steps slightly to the west from the eastern edge of the tableland (Fig. 3). Other secondary structures, including folds and a minor reverse fault, appear to be present in the hanging-wall block of the Central Range fault along this segment. South of Sanmin, the fault trace must run along the eastern base of the terraces, because there is scant evidence for fluvial erosion of the hillside by the Hsiukuluan River (Fig. 6D).

The fact that the Sanmin terraces are lower in elevation than the Wuhe Tableland indicates that the anticline beneath the terraces plunges 

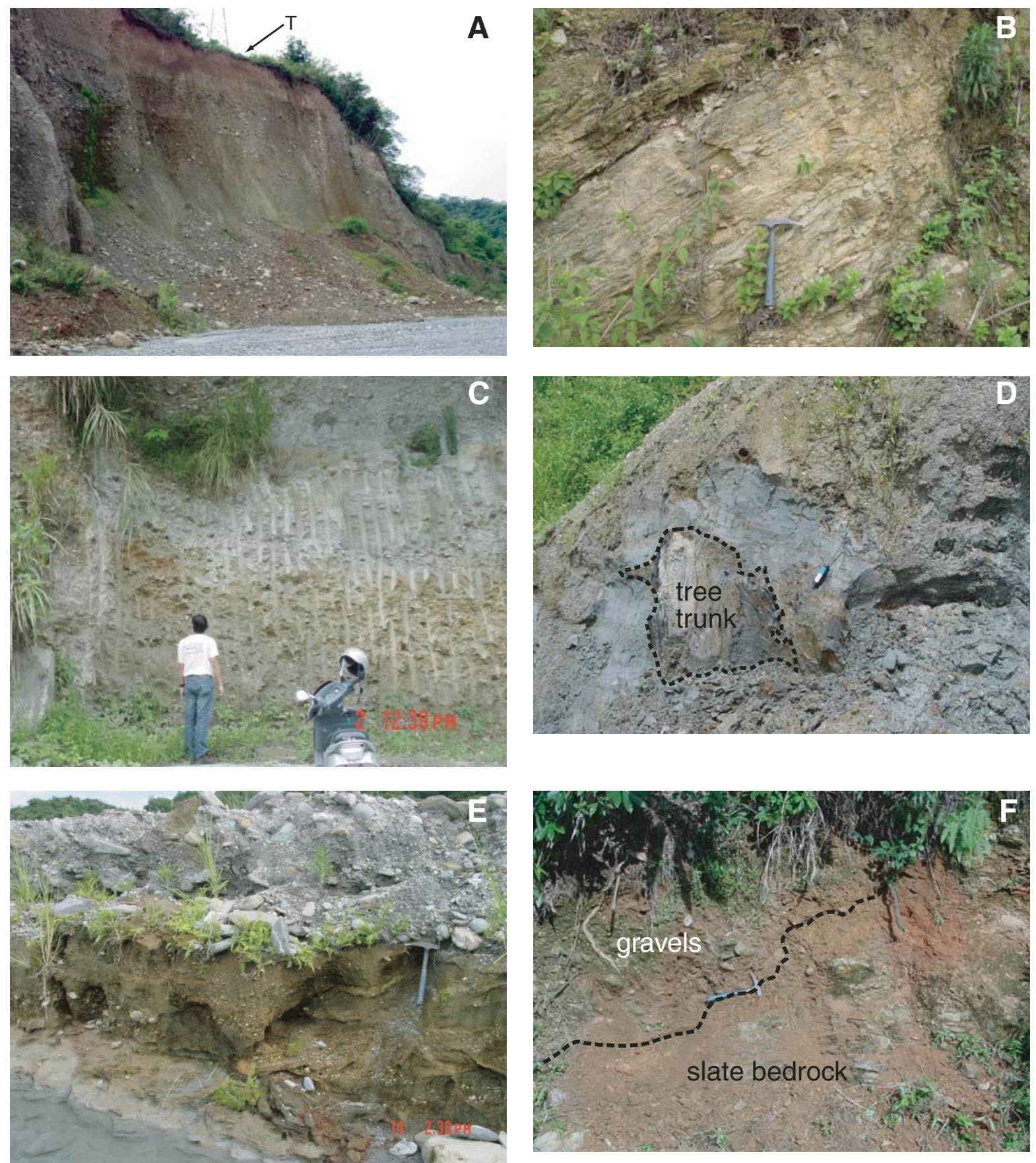

Figure 5. Selected photographs showing fluvial sediments and bedrocks of the Wuhe Tableland. (A) Along the cut bank of the Hungyeh River at the northwestern side of the tableland, the entire outcrop below the surface of the tableland (T) is composed of matrix-supported, large and angular fluvial gravels. Total height of the outcrop is $\sim 40 \mathrm{~m}$. The photo was taken at site A in Figure 4 . (B) Along the Hsiukuluan River at the southeastern side of the tableland, scattered metamorphic rocks, mostly slates, crop out as the basement of the fluvial sediments. The length of the hammer is $\sim 30 \mathrm{~cm}$. The photo was taken at site B in Figure 4. (C) The southeastern parts of the fluvial deposits beneath the Wuhe Tableland include smaller, more rounded and clast-supported gravels and more frequent fine-grained layers. The person is $\sim 1.8 \mathrm{~m}$ tall. The photo was taken at site $C$ in Figure 4. (D) The fine-grained fluvial sediments of southeastern Wuhe Tableland include occasional mud layers with tree trunks. Length of the scraper is $\sim 25 \mathrm{~cm}$. The photo was taken at site D in Figure 4. (E) In the current Hungyeh River bed, an outcrop of tan-colored, gently tilting indurated gravels and sand appears to be equivalent to deeper Wuhe Tableland sediments. These sediments are overlain by grayish-colored current Hungyeh River deposits. Strike and dip of the indurated beds are $\mathrm{N82}^{\circ} \mathrm{E}$ and $12^{\circ}$ to the northwest. This indicates that the syncline bounding the northwestern side of the tableland should be located north of the Hungyeh River. Length of the hammer is $\sim 30 \mathrm{~cm}$. The photo was taken at site $\mathrm{E}$ in Figure 4. (F) On the western flank of the Wuhe Tableland, fluvial gravels deposit on an erosional strath (shown in dashed line) on the slate bedrock. No fault is present between the Wuhe sediments and the slate formations. Length of the hammer is $\sim 30 \mathrm{~cm}$. The photo was taken at site F in Figure 4. 


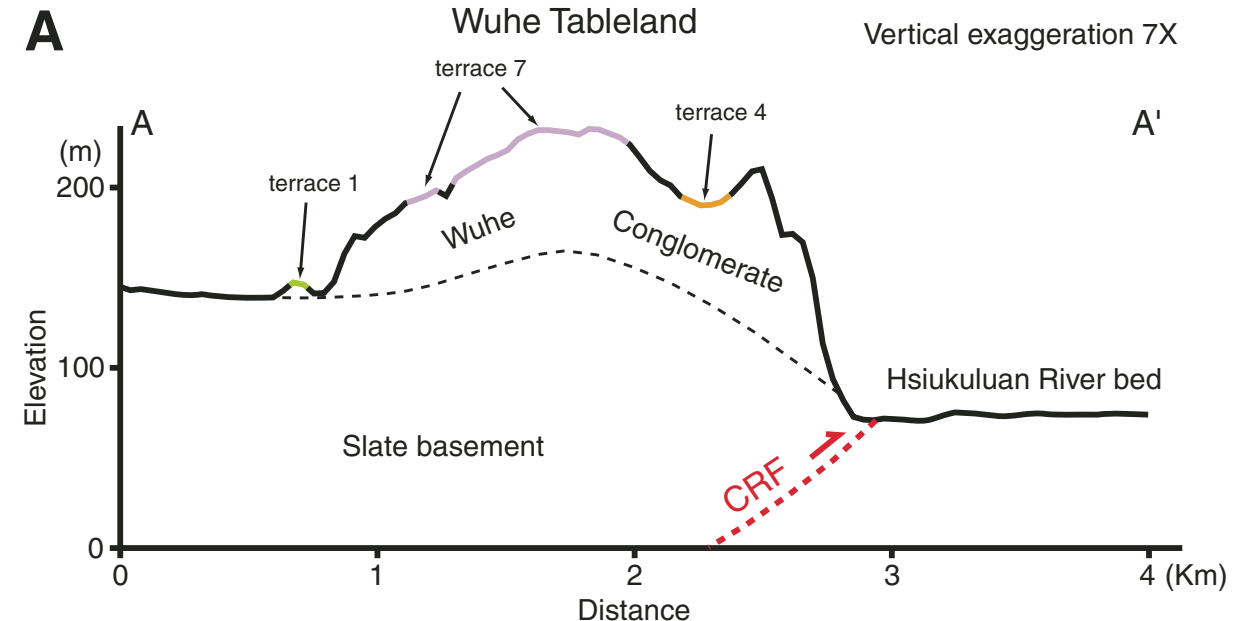

B

Vertical exaggeration 7X

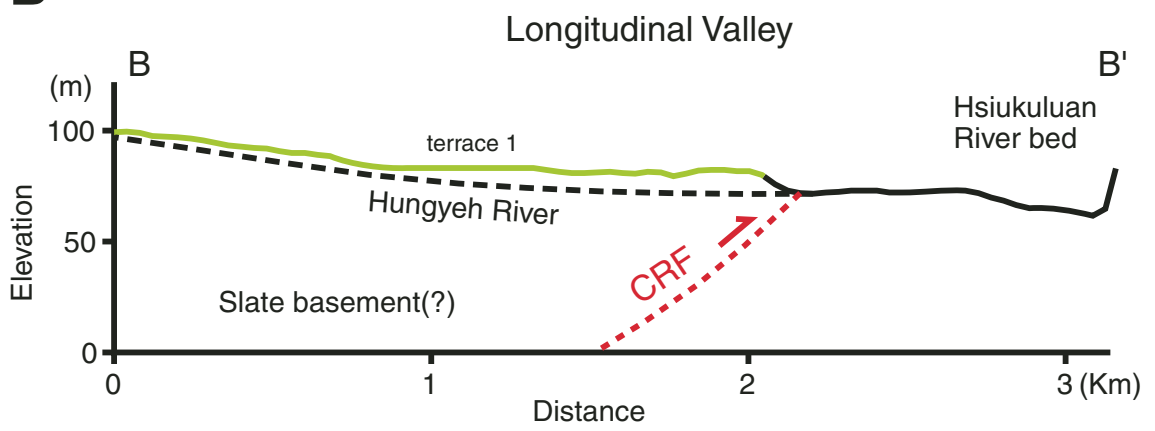

C

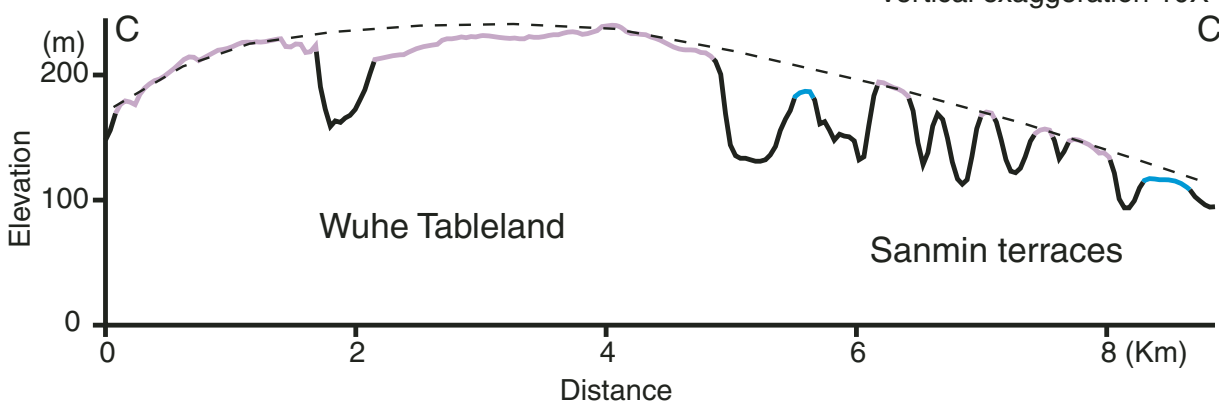

Figure 6. Selected topographic profiles in the Wuhe Tableland area. Locations of the profiles are shown in Figure 3. (A) Across the Wuhe Tableland, warped fluvial terraces on top of the tableland clearly show the deformation by the secondary folds in the hanging-wall block of the Central Range fault (CRF). The fault trace is probably very close to the eastern base of the tableland. (B) Terrace 1 of the Hungyeh River, previously part of the Hungyeh River alluvial fan, has risen and tilted upstream in association with slip along the Central Range fault. (C) A topographic profile extending from the Wuhe Tableland to the Sanmin terraces shows that most of the Sanmin terraces are , correlative with the Wuhe Tableland surface, as shown by the thin dashed line. This topographic profile indicates that the anticline underlying these surfaces plunges both to the north and to the south. (D) Lateritic terraces 7 and 8 are uplifted Hsiukuluan River beds, formed by slip along the Central Range fault. A secondary reverse fault in the hanging-wall block of the fault may have deformed the terrace 8 surface.
D

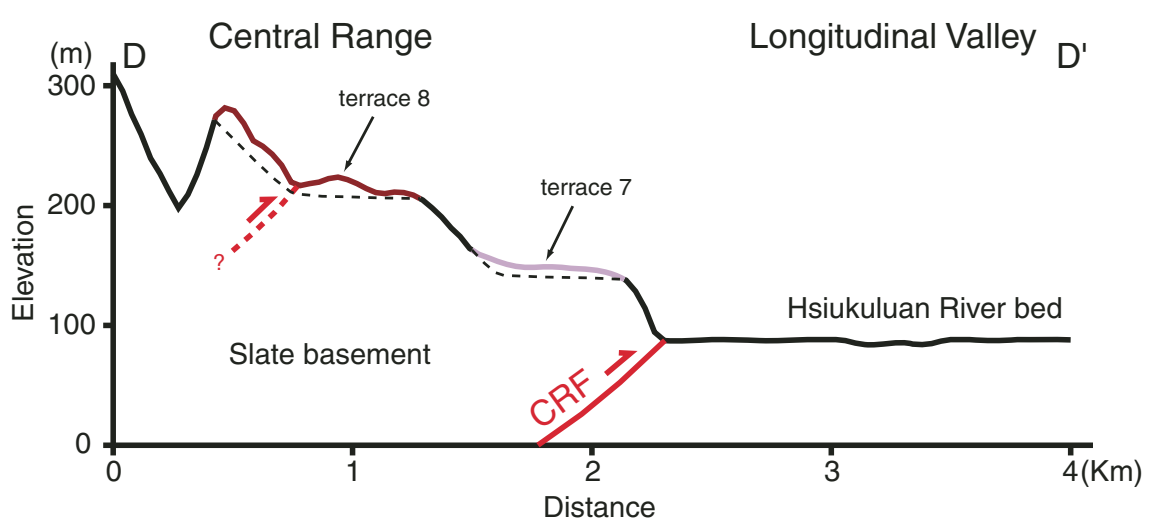

Vertical exaggeration $5 X$ 
to the south. As the anticline plunges, another anticline appears to its west and forms the linear, N-S-trending ridge southwest of Sanmin (Fig. 3). This ridge is nearly devoid of strath terraces, but is also a topographic manifestation of the Central Range fault. The highest terrace west of Sanmin, north of this ridge, is likely the uplifted riverbed of the Taiping River, formed at a time when the river flowed directly southeastward into the Longitudinal Valley. The cur- rent bed of the Taiping River, however, turns southwestward and flows parallel to the ridge for $\sim 4 \mathrm{~km}$ before cutting through the ridge to the valley. This geometry suggests that the river has been diverted around an actively rising anticlinal ridge on the hanging-wall block of the Central Range fault. Scattered fluvial terraces on this ridge may be uplifted remnants of the Taiping River bed during its southwestward diversion.

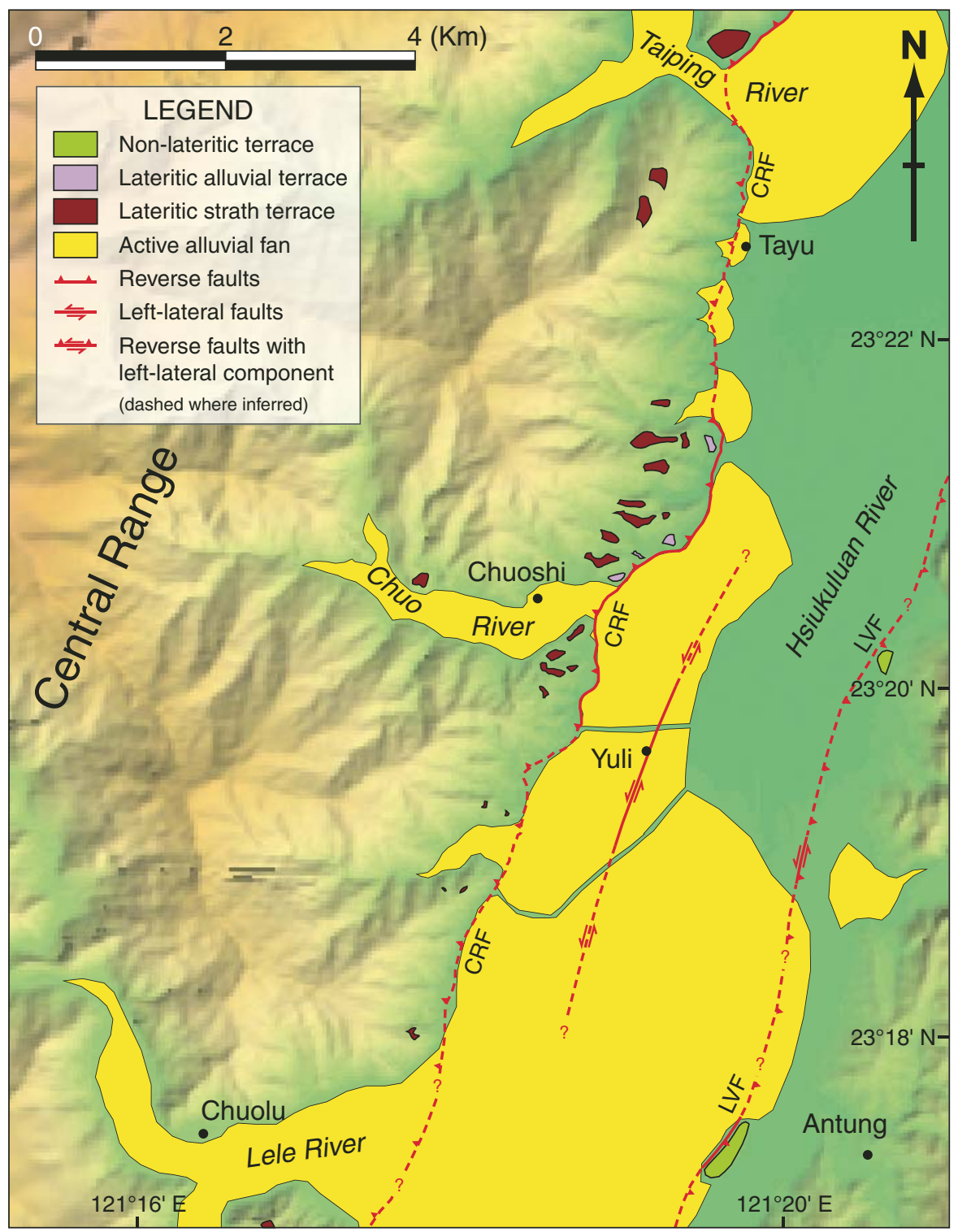

Figure 7. Detailed map of geomorphic and neotectonic features south of the Wuhe Tableland, from the Taiping River to the Lele River. North and west of Yuli, numerous uplifted lateritic strath terraces along the eastern flank of the Central Range indicate the presence of the Central Range fault (CRF) along the western edge of the Longitudinal Valley. Some fluvial terraces along the eastern side of the Longitudinal Valley, deformed by the east-dipping Longitudinal Valley fault (LVF), as well as the left-lateral surface rupture of November 1951 that runs through the town of Yuli (Shyu et al., 2006b), are also shown in the figure.

\section{THE CENTRAL RANGE FAULT SOUTH OF THE TAIPING RIVER}

South of the Taiping River, uplifted lateritic strath terraces along the eastern flank of the Central Range and numerous triangular facets along the eastern Central Range front indicate that the Central Range fault extends still further to the south. We have investigated several of these terraces in the field and have inferred the rest from their geomorphic manifestation. These expressions of uplift are particularly clear west and north of Yuli (Fig. 7). The terraces near Yuli are uplifted riverbeds of the Hsiukuluan River and its tributary, the Chuo River. The majority of these terraces currently sits more than $100 \mathrm{~m}$ above the valley floor. The higher terraces have very thin fluvial sedimentary cover, less than a few meters thick. Some lower terraces, however, are underlain by thicker fluvial sediments and thus appear to be alluvial (or fill) terraces.

Between Yuli and the Lele River, geomorphic manifestations of the Central Range fault are sparse (Fig. 7). However, very clear tectonic landforms exist south of the Lele River (Fig. 8). Immediately south of the Lele River, west of the small village of Changliang, is a small $\mathrm{N}$ $\mathrm{S}$-trending ridge. The southern half of the ridge consists of thick fluvial gravels surmounted by a lateritic terrace surface (Fig. 9). The northern, higher half of the ridge, however, consists of slate, topped locally by lateritic strath terraces. This geometry indicates that the southern half of the ridge represents an uplifted paleochannel of the southern branch of the Lele River, which formed at a time when the tributary flowed directly into the Longitudinal Valley. As the eastern flank of the Central Range uplifted along the Central Range fault, the tributary was forced to flow northward and join the Lele River just south of Chuolu. This is analogous to the diversion of the Taiping River, mentioned previously. The trace of the Central Range fault must be very close to the base of the eastern flank of the Central Range because the Hsiukuluan River currently flows along the eastern side of the Longitudinal Valley and is therefore unlikely to have eroded the fault scarp.

Farther to the south, another well-constrained location of the Central Range fault is just north of the village of Kufeng (site $G$ in Fig. 8). An uplifted alluvial fan there is warped at the mountain-front, forming a scarp on the alluvial fan that is steeper than the original fan slope (Fig. 10). Offset across the scarp is at least $10 \mathrm{~m}$. The broad, shallow nature of the scarp suggests that the fault does not break the surface; instead, the deformation of the alluvial fan is likely the manifestation of a fault-propagation fold above a blind Central Range fault. 
Numerous lateritic strath terraces on the eastern flank of the Central Range show that the Central Range fault extends still farther to the south, from Kufeng to near Chihshang. These terraces are especially large near the village of Luntien (Fig. 8). The exact location of the fault in this segment of the fault is again unclear due to possible fluvial erosion of the eastern flank of the Central Range by the Hsiukuluan River.

\section{THE BLIND CENTRAL RANGE FAULT SOUTH OF CHIHSHANG}

Uplifted lateritic terraces are very scarce along the eastern flank of the Central Range south of Chihshang. Thus, the Central Range fault must be either inactive or blind there. We favor the latter hypothesis, because many of the major Central Range rivers south of Chihshang have incised into their large alluvial fans in the Longitudinal Valley (Fig. 11A). The large alluvial fan terrace of the Peinan River, on which the town of Chihshang sits, is a prominent example (Chang et al., 1994; Fig. 11). This is consistent with regional uplift of the western Longitudinal Valley above a blind Central Range fault.

Farther to the south, near the southern end of the Longitudinal Valley, our previous mapping (Shyu et al., 2002) suggests that the active Central Range fault is overridden by a western branch of the Longitudinal Valley fault. Thus, the Central Range fault is probably active but blind from Chihshang to the southern end of the Longitudinal Valley.

\section{DISCUSSION}

\section{Geodetic and Seismic Evidence}

Several other, independent lines of evidence support the existence of the Central Range fault. In fact, it was this other evidence that compelled us to search for tectonic landforms along the eastern flank of the Central Range. The evidence includes geodetic measurements and seismic-refraction lines across the eastern flank of the Central Range, mostly done more than a decade ago. More recently, relocated earthquake hypocenters of background seismicity and aftershocks of the Chengkung earthquake of 10 December $2003\left(M_{L}=6.5\right)$ provided additional insight about the Central Range fault.

A leveling line that extends $16 \mathrm{~km}$ into the Central Range near Chihshang shows tilt of the easternmost $16 \mathrm{~km}$ of the range at $\sim 0.8 \mu$ radian/ yr between 1984 and 1987 (Liu and Yu, 1990). Thus, the westernmost point of the leveling profile, $16 \mathrm{~km}$ into the range, is rising $\sim 13 \mathrm{~mm} / \mathrm{yr}$ relative to the Longitudinal Valley floor. This would be consistent with strain accumulating

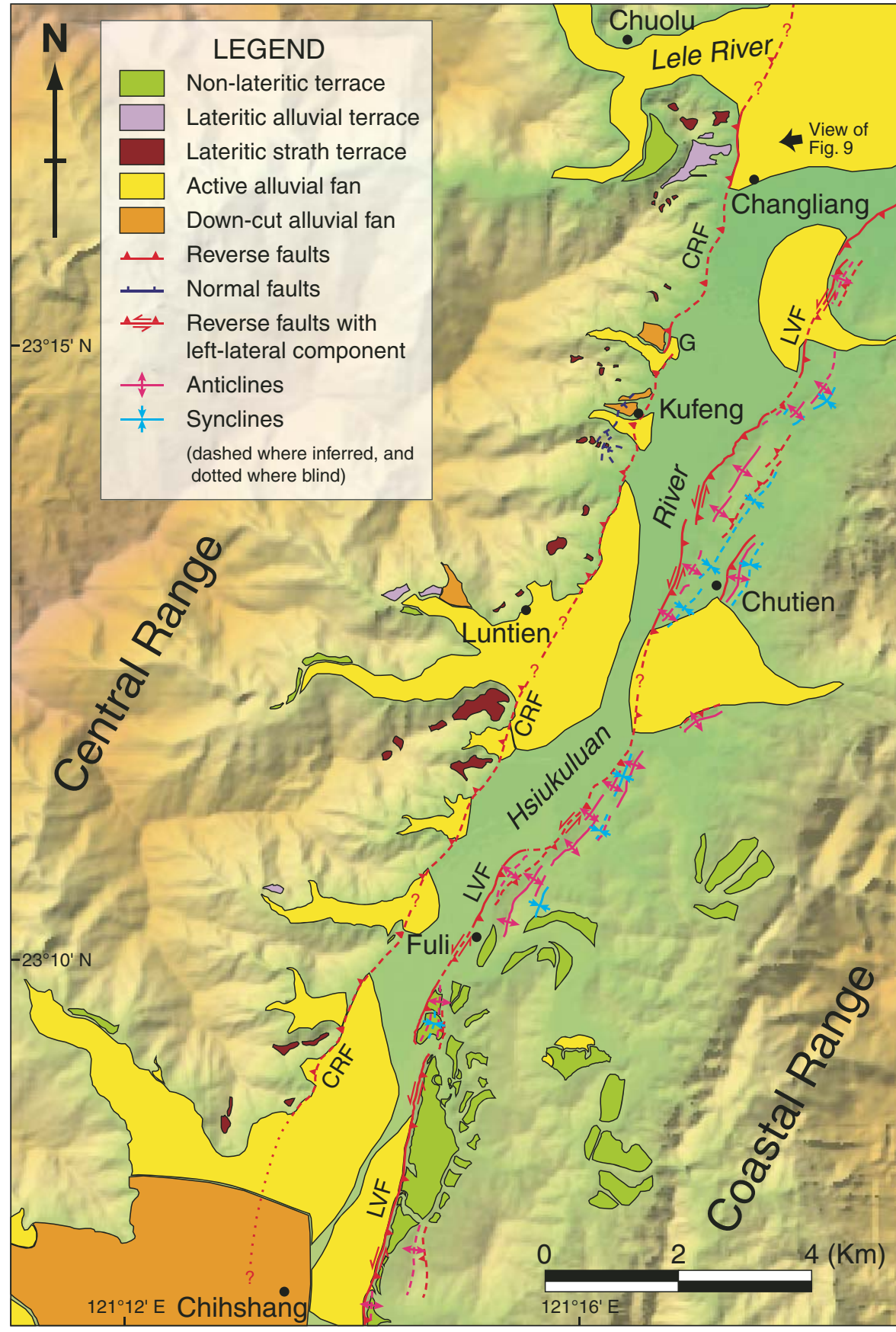

Figure 8. Detailed map of geomorphic and neotectonic features between the Lele River and Chihshang. As to the north, numerous uplifted lateritic strath terraces and deformed alluvial fans along the eastern flank of the Central Range indicate that the Central Range fault (CRF) is present along the western edge of the Longitudinal Valley. Fluvial terraces and neotectonic landforms of the east-dipping Longitudinal Valley fault (LVF), along the eastern side of the Longitudinal Valley, are also shown in the figure.

across a locked Central Range reverse fault beneath the eastern flank of the range. Unfortunately, the short length of leveling profile hampered further modeling of the result; therefore, we could not discriminate the possibility of an east-dipping normal fault for producing the tilting pattern. More recent leveling, west of Yuli, shows similar but less well-constrained eastward tilting of the eastern Central Range (Yu and Kuo, 2001). 

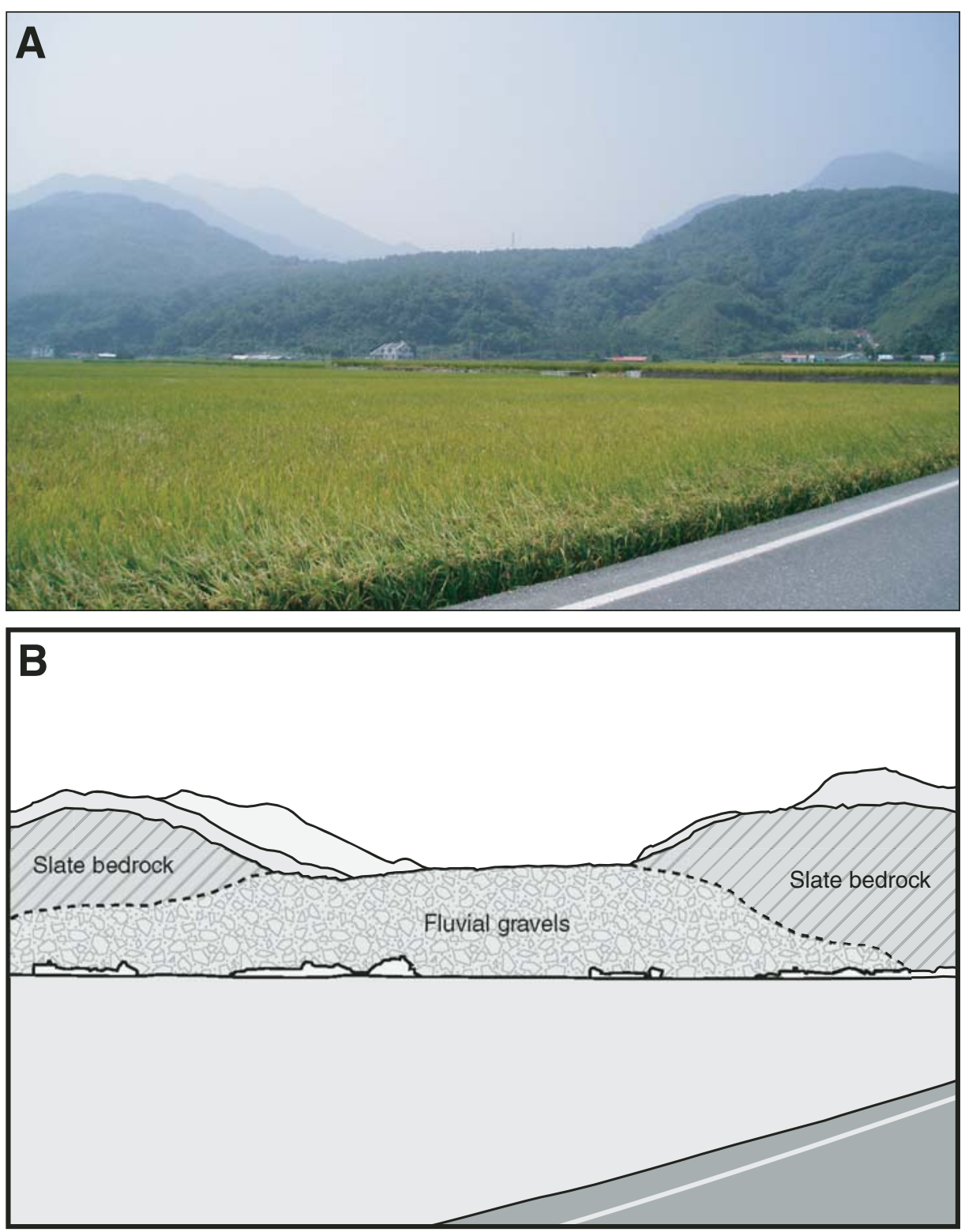

Figure 9. Photograph (A) and sketch (B) of a large N-S-trending ridge, south of the Lele River and west of Changliang. The view is toward the west, as shown by the black arrow in Figure 8. The southern half of the ridge is an alluvial terrace underlain almost entirely by fluvial gravels. It appears to be an uplifted paleochannel of the southern tributary of the Lele River, formed at a time when the tributary flowed directly into the Longitudinal Valley.

Because the Longitudinal Valley is underlain by a thick pile of coarse fluvial gravels, seismic surveys have not been able to provide much useful information about the subsurface structure of the valley. About three decades ago, though, a seismic-refraction survey revealed that at the western edge of the Longitudinal Valley, a high-speed $(\sim 6.2 \mathrm{~km} / \mathrm{s})$ unit exists in the shallow subsurface, in direct contact with a low-speed $(3.2-4.3 \mathrm{~km} / \mathrm{s})$ unit to the east. This contact may be the Central Range fault (Chen beneath the eastern Central Range is very sparse, and earthquakes there do not generally delineate well-defined fault planes or show consistent fault-plane solutions (e.g., Wu et al., 2004). A small cluster of earthquakes near Yuli, however, appears to illuminate a west-dipping plane beneath the eastern flank of the Central Range (Carena et al., 2001). This plane may be a piece of the Central Range fault. Moreover, another small cluster of relocated aftershocks of the 2003 Chengkung earthquake, near the southern end of the Longitudinal Valley, may also illuminate another piece of the Central Range fault; some of the aftershocks in this cluster show earthquake focal mechanisms consistent with a west-dipping reverse fault (Kuochen et al., 2006).

\section{Sense of Slip and Slip Rate of the Central Range Fault}

One of the major controversies about the Central Range fault, at least among those who believe in its existence, is the fault's sense of slip. Some maintain that it is an east-dipping normal fault (e.g., Crespi et al., 1996; Lee et al., 2001, 2003). Normal dip slip would provide a mechanism for the exhumation of high-pressure metamorphic rocks found locally in the eastern Central Range. The mechanism would therefore be similar to the "return flow" or "upward extrusion" mechanisms for the ascent of high-pressure metamorphic rocks to Earth's surface, as proposed for the Alps and predicted by physical models (e.g., Michard et al., 1993; Chemenda et al., 1995; Gerya et al., 2002).

In this case, though, the geometrical relationship between the Central Range fault and the high-pressure metamorphic rocks does not support this explanation. If the Central Range fault is the east-dipping normal fault responsible for the extrusional exhumation of the high-pressure rocks, the rocks need to be in contact with the low-pressure rocks along the fault. Although high-quality bedrock mapping is scarce in the eastern Central Range because of poor exposure, no high-pressure metamorphic rock is known to abut the Central Range fault. Instead, these rocks usually occur as blocks surrounded by slate and schists within the Central Range. Furthermore, according to classic models of extrusional exhumation that are based upon numerical simulation and field observations, a reverse fault needs to be present west of the high-pressure metamorphic rocks, forming the floor of the high-pressure terrane (e.g., Chemenda et al., 1995; Maruyama et al., 1996). No such fault is present west of the high-pressure rocks within the Central Range.

Rather, our geomorphic analysis of the Central Range fault indicates that the fault is a 
west-dipping reverse fault, at least at shallow depths. The secondary folds that exist west of the fault on the Wuhe Tableland and around the Taiping River and the monoclinally warped surface near Kufeng are all consistent with a reverse sense of slip along the Central Range fault. An east-dipping normal fault along the eastern Central Range front could also produce the uplifted river terraces that we see on the eastern flank of the Range, but the anticlines and monoclines would not be expected.

At present, the slip rate of the Central Range fault is poorly constrained. The surface of the Wuhe Tableland is probably older than $50 \mathrm{ka}$ and is now $\sim 170 \mathrm{~m}$ above the Hsiukuluan River bed. If the current Hsiukuluan River bed were correlative with the Wuhe Tableland surface, the uplift rate of the tableland surface could be no more than $\sim 3.4 \mathrm{~mm} / \mathrm{yr}$. However, our recent investigation on the slip rate of the Longitudinal Valley fault suggests that the Longitudinal Valley floor may be subsiding and underthrusting along both the Longitudinal Valley fault and the Central Range fault (Shyu et al., 2006a). This indicates that the total uplift of the Wuhe Tableland surface is greater than $170 \mathrm{~m}$, which implies that the uplift rate of the tableland surface should be higher than $3.4 \mathrm{~mm} / \mathrm{yr}$. We proposed a $3 \mathrm{~mm} / \mathrm{yr}$ subsidence rate of the Longitudinal Valley floor in our investigation of the Longitudinal Valley fault near Rueisuei (Shyu et al., 2006a). Assuming this value, the maximum uplift rate of the Wuhe Tableland surface should be $\sim 6.4 \mathrm{~mm} / \mathrm{yr}$. If the Central Range fault dips at 30 degrees westward, a typical dip for a reverse fault, the maximum slip rate along the fault would be $\sim 12.8 \mathrm{~mm} / \mathrm{yr}$. The resulting horizontal shortening rate of $\sim 11.1 \mathrm{~mm} / \mathrm{yr}$ summed with the $\sim 29 \mathrm{~mm} / \mathrm{yr}$ maximum horizontal shortening proposed for the Longitudinal Valley fault (Shyu et al., 2006a) yields a combined rate that is consistent with the $\sim 40 \mathrm{~mm} / \mathrm{yr}$ of total shortening across the Longitudinal Valley observed by global positioning system (Hsu et al., 2003). However, this calculation may significantly overestimate the actual rate if, for example, the fault dip is steeper, or if the Wuhe Tableland surface is much older than $50 \mathrm{ka}$.

These calculations assume that the $50 \mathrm{ka}$ minimum age for the Wuhe Tableland is the actual age. If, however, the age of the tableland is greater, the slip rate would be lower. A comparison of the development of the soil atop the tableland with lateritic soils elsewhere in Taiwan provides some constraints on how much older the tableland could be. The lateritic soil atop the Wuhe Tableland is much less than half as thick as and much less developed than the lateritic soil atop the Linkou Tableland in northwestern Taiwan (e.g., Lee et al., 1999).
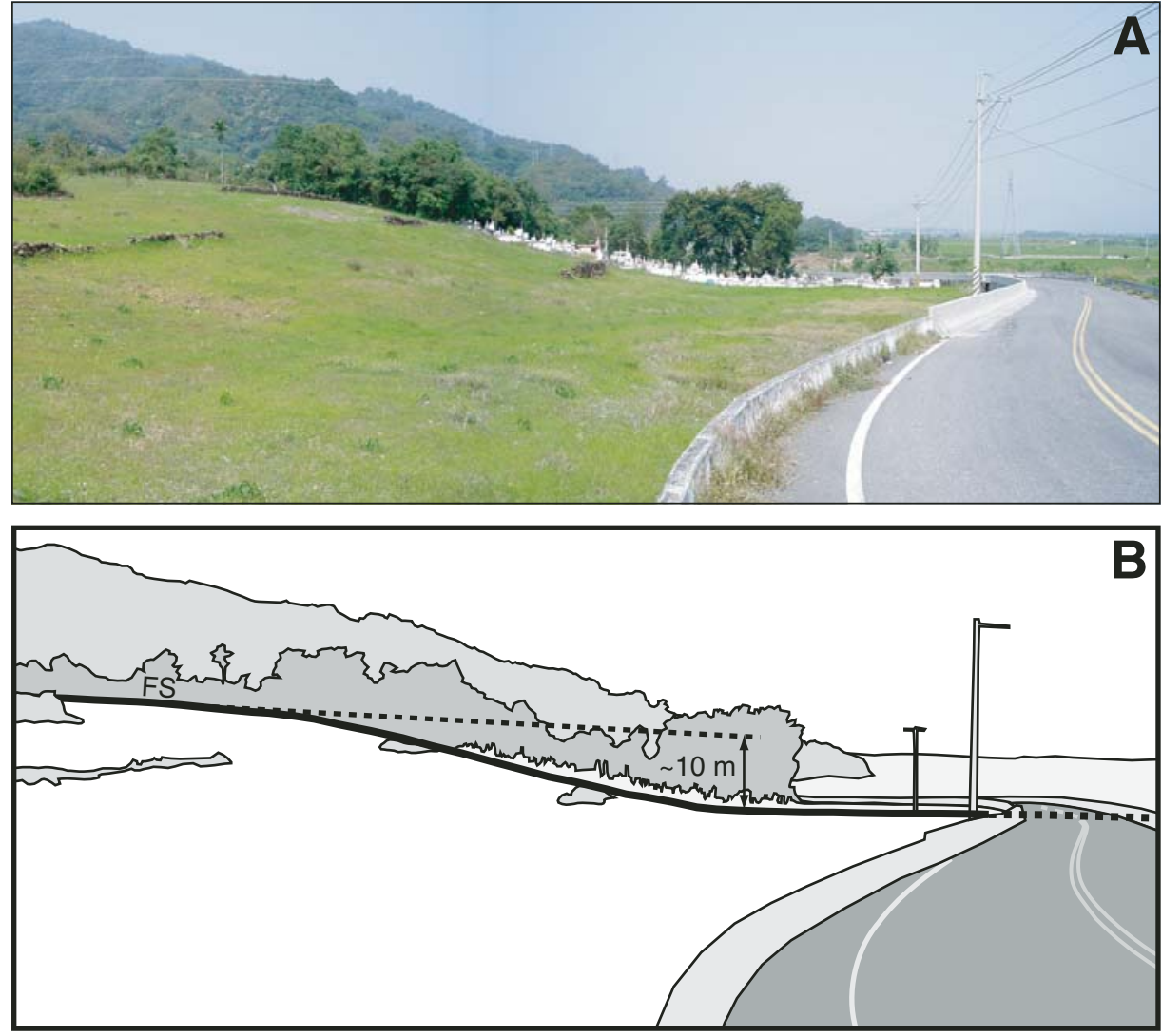

Figure 10. Photograph (A) and sketch (B) of a deformed alluvial fan surface (FS), at site G in Figure 8. View is toward the north. The undeformed part of the fan surface dips eastward $\sim 3.2^{\circ}$, and the deformed part of the fan surface dips much steeper, at $\sim 14^{\circ}$. We interpret this gentle monocline to be the eastern flank of a fault-propagation fold, caused by $\sim 10 \mathrm{~m}$ of slip on the Central Range fault in the shallow subsurface.

This implies that the surface of the Wuhe Tableland is much younger than that of the Linkou Tableland, which is generally considered to be $\sim 400 \mathrm{ka}$ based upon thermoluminescence and other dating techniques (e.g., Wei et al., 1998). Furthermore, the lateritic soil atop the Wuhe Tableland is similar to that atop a 92-ka tilted terrace found near the southern end of the Chelungpu fault, western Taiwan (Ota et al., 2002). Thus, the maximum age for the Wuhe Tableland is close to $92 \mathrm{ka}$ and much younger than $400 \mathrm{ka}$. A conservative assumption of $200 \mathrm{ka}$ yields a minimum uplift rate of $\sim 0.9 \mathrm{~mm} / \mathrm{yr}$. Applying the same calculation of the subsidence and the fault dip as before, the minimum slip rate along the fault would be $\sim 7.8 \mathrm{~mm} / \mathrm{yr}$.

The constraint of less than $12.8 \mathrm{~mm} / \mathrm{yr}$ for the slip rate of the Central Range fault suggests that the fault is absorbing much less than half of the shortening across the Longitudinal Valley suture, as we (Shyu et al., 2006a) have shown that the slip rate along the Longitudinal Valley fault is $\sim 23 \mathrm{~mm} / \mathrm{yr}$. The constraint also indicates that, in the very long term, the earthquake production rate of the Central Range fault is smaller than that of the Longitudinal Valley fault. That is, for a given magnitude of slip, an event should occur on the Longitudinal Valley fault at least twice as frequently as on the Central Range fault.

\section{The Evolution of the Longitudinal Valley Suture}

Although the Central Range fault is absorbing only a small portion of the horizontal shortening across the Longitudinal Valley suture at present, we believe it may have played a more important role in the evolution of the suture. Recently, we proposed a model for the northward maturation of the suturing between the Luzon volcanic arc and the Central Range continental sliver, in which the development of multiple reverse-fault wedges facilitates the thickening of the margins of both nonoceanic blocks at the suture and creates a "Christmas tree" shape for the Longitudinal Valley suture (Shyu et al., 2006a; Fig. 12). In 

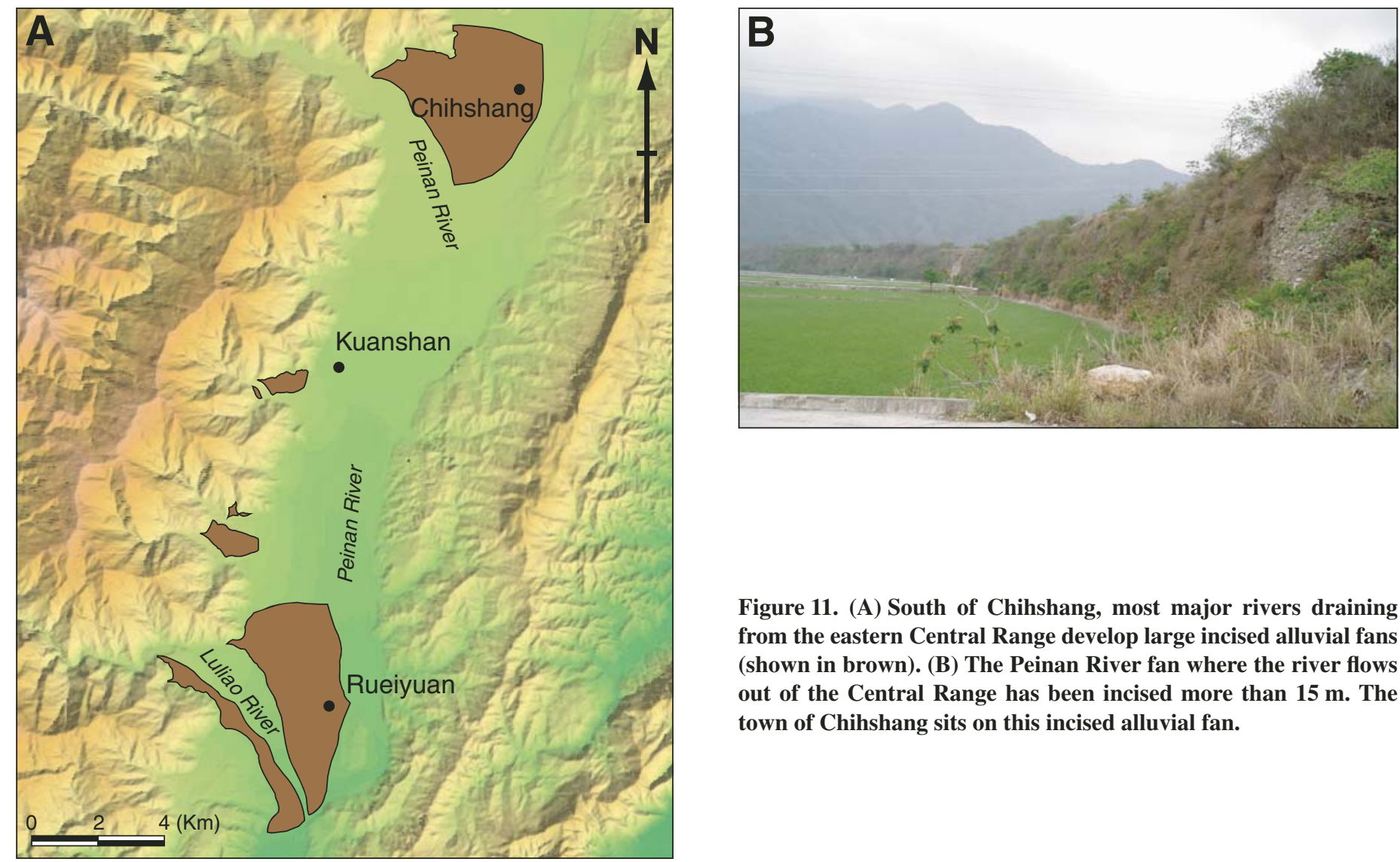

Figure 11. (A) South of Chihshang, most major rivers draining from the eastern Central Range develop large incised alluvial fans (shown in brown). (B) The Peinan River fan where the river flows out of the Central Range has been incised more than $15 \mathrm{~m}$. The town of Chihshang sits on this incised alluvial fan.

Figure 12. Schematic crustal cross sections show our hypothesis for the evolution of the Longitudinal Valley suture. Each section is drawn using current topography and observations along the lines specified on the index map, with no vertical exaggeration. Red indicates the youngest and currently active faults in each time frame, and blue indicates older faults, which may still be active. Faults are dashed where inferred. (A) Before suturing, the Luzon forearc oceanic lithosphere (FAO) subducts beneath the Central Range continental sliver (CR). This is currently occurring at about the latitude of the southern tip of Taiwan, $\sim 22^{\circ} \mathrm{N}$. (B) As the Luzon volcanic arc lithosphere (LVA) approaches the Central Range, an east-dipping thrust fault appears, allowing the forearc oceanic lithosphere to also subduct underneath the volcanic arc lithosphere. Contemporaneously on the west side of the valley, the proximity of the Luzon volcanic arc lithosphere to the Central Range continental sliver induces formation of a newer, shallower west-dipping thrust fault above the original one. This is the current structural geometry near the southern end of the Longitudinal Valley, between $\sim 22^{\circ} 40^{\prime} \mathrm{N}$ and $22^{\circ} 50^{\prime} \mathrm{N}$. (C) As the suture matures, the two nonoceanic lithospheric blocks both start to thicken by evolving multiple reverse-fault wedges, with the younger ones at shallower depth. This is the current structural geometry at the latitude of Chihshang, $\sim 23^{\circ} 10^{\prime} \mathrm{N}$. (D) At the latitude of the Wuhe Tableland, $\sim 23^{\circ} 30^{\prime} \mathrm{N}$, the suture is nearing maturity. The suture has evolved into a "Christmas tree" shape; there is a thick pile of sediments between the two nonoceanic lithospheric blocks and underlain by the subducted forearc oceanic lithosphere. (E) In northern Longitudinal Valley, at the latitude $\sim 23^{\circ} 45^{\prime} \mathrm{N}$, the dominantly sinistral Longitudinal Valley fault appears to be the only major active structure. The west-dipping Central Range fault has become inactive, and sediments in the Longitudinal Valley are lapping on the eastern flank of the Central Range. Frames A to D are from Shyu et al. (2006a). Relocated earthquake hypocenters in C and D were adapted from Kuochen et al. (2004). 

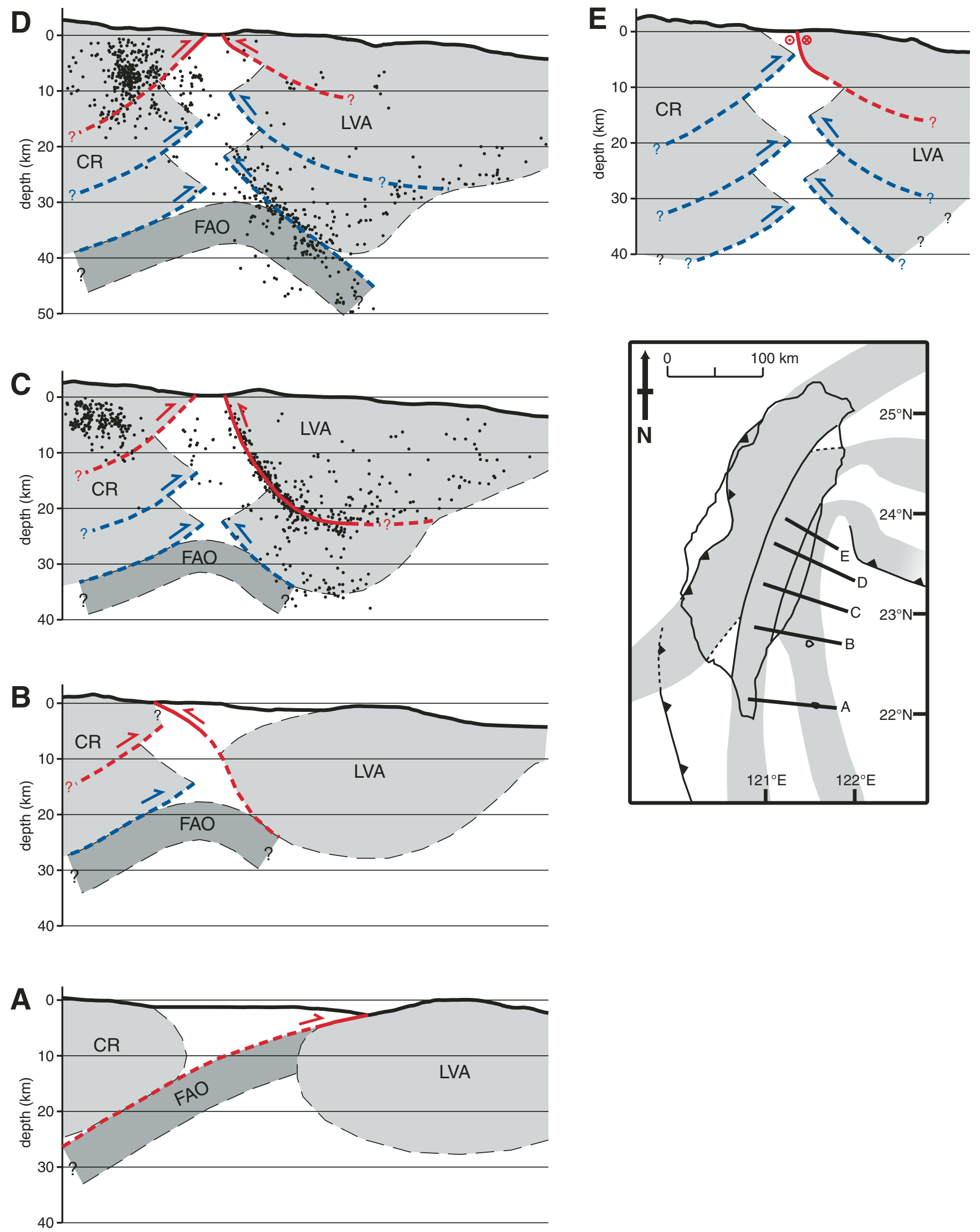
such a model, the current Central Range fault is likely to be the youngest of several generations of reverse faults on the western side of the suture.

Farther to the south, near the southern tip of Taiwan, bathymetric evidence suggests that a west-dipping thrust fault along the eastern edge of the forearc basin is the major structure responsible for the closure of the forearc basin (Shyu et al., 2005a; Fig. 12A). This is probably the first generation of this family of west-dipping faults. As the suture became more developed to the north, the east-dipping Longitudinal Valley fault appeared at the southern end of the Longitudinal Valley (Fig. 12B). There, the Central Range fault appears to be blind and overridden by the Longitudinal Valley fault (Shyu et al., 2002). As our geomorphic analysis suggests, the Central Range fault becomes emergent father to the north (Figs. 12C and 12D).

The geometry of the Central Range fault near Rueisuei suggests that it may be overridden again by the Longitudinal Valley fault north of the Wuhe Tableland (Fig. 3). Although part of the overridden segment of the Central Range fault may still be active, we believe that the fault becomes inactive immediately north of this point. Between Rueisuei and the northern end of the Longitudinal Valley, the eastern flank of the Central Range is notably more sinuous than it is to the south (Fig. 2). The higher sinuosity indicates that rates of uplift of the range are much lower than rates of alluvial deposition. This hypothesis is supported by the rarity of lateritic fluvial terraces along the eastern flank of the range along this reach of the valley (Chang et al., 1992). Thus, it appears that the Longitudinal Valley fault is the solitary major active structure along the northern part of the Longitudinal Valley suture (Fig. 12E). The inactivity of all reverse-fault wedges on the suture's western side would be an indication that the suture is fully developed; that is, the volcanic arc has docked fully with the continental sliver of the Central Range.

\section{The Central Range Fault, Uplift of the Central Range, and Crustal Thickening}

The Central Range is the mountainous backbone of Taiwan, with highest peaks rising nearly $4 \mathrm{~km}$ above sea level. Yet, the mechanism responsible for the growth of such a large mountain range remains poorly understood. Rapid exhumation of the Central Range, at rates as high as $\sim 6 \mathrm{~mm} / \mathrm{yr}$ over the past several million years, has been suggested by thermochronological studies of the metamorphic rocks of the range (e.g., Jahn et al., 1986; Liu et al., 2001; Willett et al., 2003). This rate is coincident with directly measured recent erosion and fluvial incision rates over the past couple of years (e.g., Hovius et al., 2000; Hartshorn et al., 2002). Therefore, the current annual uplift rate of the range, which produced the fluvial incision, is also around several mm/yr. Although the late Quaternary uplift rate of the eastern Central Range, produced by the slip along the Central Range fault, appears to be similar to the above-mentioned annual and million-year rate, it is poorly constrained. Dating of uplifted fluvial surfaces would help to narrow the uncertainties.

No consensus exists regarding the mechanism for rapid uplift and exhumation of the Central Range. Hsu et al. (2003) analyzed horizontal and vertical global positioning system (GPS) displacements in profiles across Taiwan drawn parallel to the direction of relative plate motion. They used a complex elastic dislocation geometry to show that aseismic horizontal motions could be explained well by slip on a shallowly dipping thrust fault under the western flank of the Central Range and a steeply east-dipping Longitudinal Valley fault. They noted, however, that the rapid uplift of the Central Range is not explained by this model. Crustal thickening resulting in isostatically induced uplift may therefore be a major driving force for the uplift and exhumation (Shyu et al., 2005a, 2005b).

What role does the Central Range fault play in thickening the crust of the Central Range? Since our analysis indicates that the uplift rate of the Wuhe Tableland surface caused by the slip along the Central Range fault is comparable to the uplift and exhumation rate of the range, it is clear that localized brittle slip along the fault is an important component of the crustal thickening and uplift, at least along the eastern front of the range. We offer three scenarios for how the Central Range fault might fit into the overall uplift of the range (Fig. 13). In each case, the deepest structures are the oldest, and the shallowest structure is the currently active fault. Panel A in Figure 13 illustrates a case in which thickening of the eastern Central Range crust occurs solely by brittle slip on a family of Central Range faults. Although this may be an adequate representation of what is happening on the flank of the range, it is unlikely that brittle slip continues to greater depth, below the brittle-ductile transition. Panel B is a modification in which the faults transform downward into a broad zone, in which shortening and crustal thickening occur by ductile simple shear. In both Panel A and B, uplift of the range $(\Delta \mathrm{T})$ occurs solely as the vertical component of translation along the Central Range fault. One would expect, however, that isostatic response to this thickening of the Central Range crust would lead to isostatically driven arching of the range, as well. Another means by which a broad arching of the range could add to the uplift of the range would be pervasive processes, such as crystal plastic flow or underplating, at middleto lower-crustal levels, as illustrated in Panel C of Figure 13. This or isostatically arching of upper crust might explain observations of widespread normal faulting and geodetic extension at shallow depths across the Central Range (e.g., Crespi et al., 1996; Fisher, 1999).

Nearly three decades ago, local structural observations led to the proposal that east-vergent "backthrusting" or "backfolding" was an important structural component of the eastern Central Range (e.g., Ernst, 1977; Page and Suppe, 1981; Stanley et al., 1981). Later observations in the eastern Central Range of widespread normal faulting or oblique faulting with a normal component (e.g., Crespi et al., 1996; Fisher, 1999) appeared to contradict this. Figure 13C shows that these two ideas need not be contradictory. Better geochronologic constraints on the exhumation history of rocks in the southeastern Central Range, where the Central Range fault is clearly active, might provide a more satisfactory resolution of the kinematic details. Regional geomorphic, stratigraphic, and structural mapping of the eastern Central Range, quite sparse at present, could provide better information about the structural history of the range. Moreover, ongoing seismologic investigations of Taiwan will shed light on deeper structures beneath the Central Range that are important in its current stage of orogeny. We hope that our observations and models will stimulate such future work.

\section{CONCLUSIONS}

An abundance of young tectonic landforms along the eastern flank of the Central Range, as well as geodetic and seismic observations, reveal the presence of a west-dipping reverse fault along the western side of the Longitudinal Valley in eastern Taiwan. This Central Range fault crops out for a distance of $\sim 40 \mathrm{~km}$, from just north of the Wuhe Tableland to near Chihshang (Fig. 2). South of Chihshang, the fault is also active, but blind. The Central Range fault appears to veer toward and plunge beneath the east-dipping Longitudinal Valley fault northeast of the Wuhe Tableland and is inactive along the more northern reaches of the Longitudinal Valley.

Although a millennial slip rate of the Central Range fault is not well established, the maximum plausible rate, $\sim 12.8 \mathrm{~mm} / \mathrm{yr}$, is likely to be an overestimation. Even so, this slip rate implies that the fault is absorbing a smaller portion of the $40 \mathrm{~mm} / \mathrm{yr}$ of horizontal shortening across the Longitudinal Valley suture than the portion taken up across the Longitudinal Valley fault. 
CR

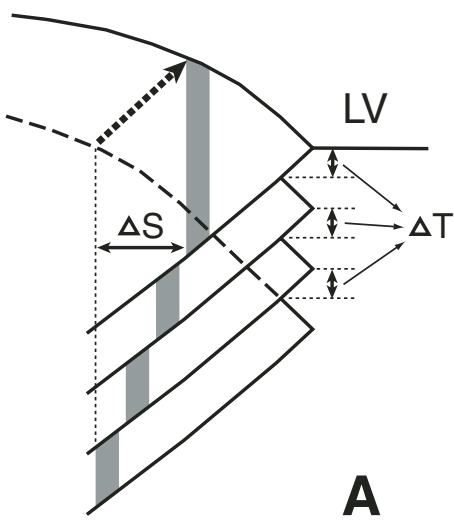

CR

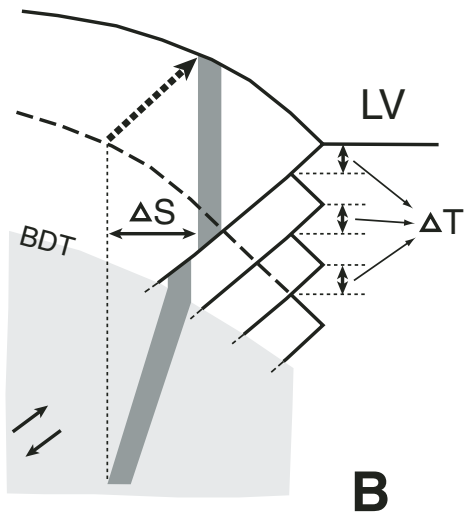

CR

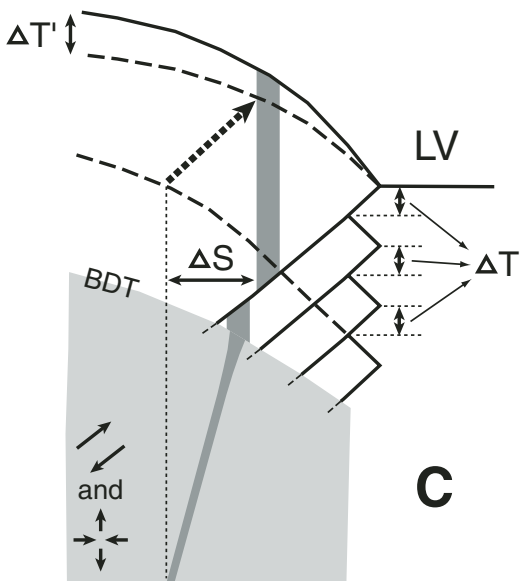

Figure 13. Cartoons showing possible scenarios of crustal thickening $(\Delta \mathrm{T})$ and shortening $(\Delta \mathrm{S})$ produced by slip along the Central Range fault and by other processes. Dark-gray bar indicates an originally vertical reference band. Bold dashed arrow indicates the direction of material movement. CR-Central Range; LV_Longitudinal Valley; BDT-brittle-ductile transition. (A) The Central Range fault system continues to depth, and brittle slip along the fault is responsible for all shortening and crustal thickening. (B) The Central Range fault system transforms downdip at the brittle-ductile transition into a ductile zone, where shortening and crustal thickening are accomplished by ductile simple shear. (C) Deformation occurs as in B, but additional shortening and crustal thickening occur beneath the Central Range by pervasive pure-shear processes, which produce an arching of the upper crust $\left(\Delta \mathbf{T}^{\prime}\right)$.

Since the slip rate of the fault is comparable to the exhumation rate of the Central Range for the past several million years, localized brittle slip along the fault appears to be an important component of the exhumation and uplift of the range. Additional shortening and crustal thickening may be produced by pervasive processes at depth, downdip from the Central Range fault.

\section{ACKNOWLEDGMENTS}

We greatly appreciate the assistance of Y. Wang and T. Watanuki in the field and are grateful for valuable discussions with J.-P. Avouac, O. Beyssac, Y.-C. Chan, H.-T. Chu, J.-C. Lee, W.-T. Liang, M. Simons, Y.-M $\mathrm{Wu}$, and S.-B. Yu. Also, we have benefited from stimulating discussions with the students of a binational field class of the National Taiwan University and Caltech, held in eastern Taiwan in 2002. Our mapping was facilitated by J. Giberson, manager of Caltech's geographic information system (GIS) laboratory. The $5 \mathrm{~m}$ digital elevation model was generously provided by the Central Geological Survey, Ministry of Economic Affairs, Taiwan. The comments and suggestions of J. Wakabayashi and two anonymous reviewers led to significant improvements of the manuscript. Our project in Taiwan was supported by National Science Foundation (NSF) grant EAR-0208505. This research was also supported in part by the Gordon and Betty Moore Foundation. This is Caltech Tectonics Observatory contribution 22 .

\section{REFERENCES CITED}

Angelier, J., Chu, H.-T., and Lee, J.-C., 1997, Shear concentration in a collision zone: Kinematics of the Chihshang fault as revealed by outcrop-scale quantification of active faulting, Longitudinal Valley, eastern Taiwan:
Tectonophysics, v. 274 , p. 117-143, doi: 10.1016/ S0040-1951(96)00301-0.

Biq, C., 1965, The East Taiwan Rift: Petroleum Geology of Taiwan, v. 4, p. 93-106.

Carena, S., Suppe, J., and Kao, H., 2001, Imaging the main detachment under Taiwan: Implications for the critical-taper mechanics and large-scale topography: Eos (Transactions, American Geophysical Union), v. 82, no. 47, F1176,

Carena, S., Suppe, J., and Kao, H., 2002, Active detachment of Taiwan illuminated by small earthquakes and its control of first-order topography: Geology, v. 30, p. 935-938, doi: 10.1130/0091-7613(2002)030<0935: ADOTIB $>2.0 . \mathrm{CO} ; 2$

Chan, C.-W., 1985, The Rueisuei, Hualien earthquake series on April 24, 1972 [M.S. thesis]: Taipei, National Taiwan University, $92 \mathrm{p}$.

Chang, J.-C., Shih, T.-T., Shen, S.-M., and Chang, C.-L., 1992, A geomorphological study of river terrace in northern Huatung Longitudinal Valley: Geographical Research, v. 18, p. 1-51.

Chang, J.-C., Shih, T.-T., Yang, S.-C., Lin, Y.-F., and Chen, H.-L., 1994, A geomorphological study of alluvial fan in Huatung Longitudinal Valley: Geographical Research, v. 21, p. 43-74.

Chang, L.-S., 1971, A biostratigraphic study of the so-called Slate Formation in Taiwan based on smaller foraminifera: I. The E-W cross-mountain highway: Proceedings of the Geological Society of China, v. 14, p. 45-61.

Chemenda, A.I., Mattauer, M., Malavieille, J., and Bokun, A.N., 1995, A mechanism for syn-collisional rock exhumation and associated normal faulting: Results from physical modeling: Earth and Planetary Science Letters, v. 132, p. 225-232, doi: 10.1016/0012-821X(95)00042-B.

Chen, H.-H., and Rau, R.-J., 2002, Earthquake locations and style of faulting in an active arc-continent plate boundary: The Chihshang fault of eastern Taiwan: Eos (Transactions, American Geophysical Union), v. 83, no. 47 , p. F1281.

Chen, J.-S., 1976, The analysis and design of refraction and reflection seismic survey of the Taitung area: Petroleum Geology of Taiwan, v. 13, p. 225-246.

Chen, J.-S., Chou, J.-N., Lee, Y.-C., and Chou, Y.-S., 1974, Seismic survey conducted in eastern Taiwan: Petroleum Geology of Taiwan, v. 11, p. 147-163.
Chen, Y.-G., 1988, C-14 dating and correlation of river terraces along the lower reach of the Tahan-chi, northern Taiwan [M.S. thesis]: Taipei, National Taiwan University, $88 \mathrm{p}$.

Chen, Y.-G., Chen, W.-S., and Chen, Y.-W., 2004, Thermoluminescence and optically stimulated luminescence dating, trenching and paleoseismologic research projects (3/5): Taipei, Central Geological Survey Report 93-6, $44 \mathrm{p}$.

Cheng, S.-N., Yeh, Y.T., and Yu, M.-S., 1996, The 1951 Taitung earthquake in Taiwan: Journal of the Geological Society of China, v. 39, p. 267-285.

Crespi, J.M., Chan, Y.-C., and Swaim, M.S., 1996, Synorogenic extension and exhumation of the Taiwan hinterland: Geology, v. 24, p. 247-250, doi: 10.1130/00917613(1996)024<0247:SEAEOT>2.3.CO;2.

Davis, D., Suppe, J., and Dahlen, F.A., 1983, Mechanics of fold-and-thrust belts and accretionary wedges: Journal of Geophysical Research, v. 88, p. 1153-1172.

Ernst, W.G., 1977, Olistostromes and included ophiolitic debris from the Coastal Range of eastern Taiwan: Geological Society of China Memoir, v. 2, p. 97-114.

Fisher, D.M., 1999, Orogen-parallel extension in the eastern Central Range of Taiwan: Journal of the Geological Society of China, v. 42, p. 41-58.

Fisher, D.M., Lu, C.-Y, and Chu, H.-T., 2002, Taiwan slate belt: Insights into the ductile interior of an arc-continent collision, in Byrne, T.B., and Liu, C.-S., eds., Geology and Geophysics of an Arc-Continent Collision, Taiwan: Geological Society of America Special Paper 358, p. 93-106.

Gerya, T.V., Stöckhert, B., and Perchuk, A.L., 2002, Exhumation of high-pressure metamorphic rocks in a subduction channel: A numerical simulation: Tectonics, v. 21 , no. 6 , p. 1056 , doi: 10.1029/2002TC001406.

Hartshorn, K., Hovius, N., Dade, W.B., and Slingerland, R.L., 2002, Climate-driven bedrock incision in an active mountain belt: Science, v. 297 , p. 2036-2038, doi: $10.1126 /$ science 1075078 .

Ho, C.S., 1986, A synthesis of the geologic evolution of Taiwan: Tectonophysics, v. 125, p. 1-16, doi: 10.1016/0040-1951(86)90004-1.

Ho, C.S., 1988, An introduction to the geology of Taiwan, explanatory text of the geologic map of Taiwan (2nd edition): Taipei, Central Geological Survey, $192 \mathrm{p}$. 
Hovius, N., Stark, C.P., Chu, H.-T., and Lin, J.-C., 2000, Supply and removal of sediment in a landslide-dominated mountain belt: Central Range, Taiwan: The Journal of Geology, v. 108, p. 73-89, doi: 10.1086/314387.

Hsu, Y.-J., Simons, M., Yu, S.-B., Kuo, L.-C., and Chen, H.-Y., 2003, A two-dimensional dislocation model for interseismic deformation of the Taiwan mountain belt: Earth and Planetary Science Letters, v. 211, p. 287294, doi: 10.1016/S0012-821X(03)00203-6.

Jahn, B.M., Martineau, F., Peucat, J.J., and Cornichet, J., 1986, Geochronology of the Tananao schist complex and crustal evolution of Taiwan: Geological Society of China Memoir, v. 7, p. 383-404.

Kuochen, H., Wu, Y.-M., Chang, C.-H., Hu, J.-C., and Chen, W.-S., 2004, Relocation of the eastern Taiwan earthquakes and its tectonic implications: Terrestrial, Atmospheric and Oceanic Sciences, v. 15, p. 647-666.

Kuochen, H., Wu, Y.-M., Chen, Y.-G., and Chen, R.-Y., 2006, 2003 Mw6.8 Chengkung earthquake and its related seismogenic structure: Journal of Asian Earth Sciences (in press)

Lallemand, S., and Liu, C.-S., 1998, Geodynamic implications of present-day kinematics in the southern Ryukyus: Journal of the Geological Society of China, v. 41, p. 551-564.

Lee, J.-C., Angelier, J., Chu, H.-T., Hu, J.-C., and Jeng, F. S., 2001, Continuous monitoring of an active fault in plate suture zone: A creepmeter study of the Chihshang fault, eastern Taiwan: Tectonophysics, v. 333, p. 219240, doi: 10.1016/S0040-1951(00)00276-6.

Lee, J.-C., Angelier, J., Chu, H.-T., Hu, J.-C., Jeng, F.-S., and Rau, R.-J., 2003, Active fault creep variations at Chihshang, Taiwan, revealed by creep meter monitoring, 1998-2001: Journal of Geophysical Research, v. 108, no. B11, p. 2528, doi: 10.1029/2003JB002394.

Lee, T.-Q., Lin, S.-F., and Chou, H.-C., 1999, Preliminary magnetic study of the Quaternary red-soil bed on Linkou Terrace, northern Taiwan: Terrestrial, Atmospheric and Oceanic Sciences, v. 10, p. 763-776.

Lin, C.-H., 2004, Repeated foreshock sequences in the thrust faulting environment of eastern Taiwan: Geophysical Research Letters, v. 31, p. L13601, doi: 10.1029/2004GL019833.

Lin, C.-W., Chang, H.-C., Lu, S.-T., Shih, T.-S., and Huang, W.-J., 2000, An introduction to the active faults of Taiwan (2nd edition), explanatory text of the active fault map of Taiwan: Taipei, Central Geological Survey Special Publication 13, $122 \mathrm{p}$.

Liu, C.-C., and Yu, S.-B., 1990, Vertical crustal movements in eastern Taiwan and their tectonic implications: Tectonophysics, v. 183, p. 111-119, doi: 10.1016/00401951(90)90191-A.

Liu, T.-K., Hsieh, S., Chen, Y.-G., and Chen, W.-S., 2001, Thermo-kinematic evolution of the Taiwan oblique-collision mountain belt as revealed by zircon fission track dating: Earth and Planetary Science Letters, v. 186, p. 45-56, doi: 10.1016/S0012-821X(01)00232-1.
Lo, C.-H., and Onstott, T.C., 1995, Rejuvenation of K-Ar systems for minerals in the Taiwan mountain belt Earth and Planetary Science Letters, v. 131, p. 71-98, doi: 10.1016/0012-821X(95)00011-Z.

Malavieille, J., Lallemand, S.E., Dominguez, S., Deschamps, A., Lu, C.-Y., Liu, C.-S., Schnürle, P., and the ACT scientific crew, 2002, Arc-continent collision in Taiwan: New marine observations and tectonic evolution, in Byrne, T.B., and Liu. C.-S., eds., Geology and Geophysics of an Arc-Continent Collision, Taiwan: Geological Society of America Special Paper 358, p. 187-211.

Maruyama, S., Liou, J.G., and Terabayashi, M., 1996, Blueschists and eclogites of the world and their exhumation: International Geology Review, v. 38, p. 485-594.

Michard, A., Chopin, C., and Henry, C., 1993, Compression versus extension in the exhumation of the Dora-Maira coesite-bearing unit, western Alps, Italy: Tectonophysics, v. 221, p. 173-193, doi: 10.1016/0040-1951(93)90331-D.

Ota, Y., Shyu, J.B.H., Chen, Y.-G., and Hsieh, M.-L., 2002, Deformation and age of fluvial terraces south of the Choushui River, central Taiwan, and their tectonic implications: Western Pacific Earth Sciences, v. 2, p. 251-260.

Page, B.M., and Suppe, J., 1981, The Pliocene Lichi mélange of Taiwan: Its plate-tectonic and olistostromal origin: American Journal of Science, v. 281, p. 193-227.

Sella, G.F., Dixon, T.H., and Mao, A., 2002, REVEL: A model for recent plate velocities from space geodesy: Journal of Geophysical Research, v. 107, no. B4, p. 2081, doi: 10.1029/2000JB000033.

Shyu, J.B.H., Sieh, K., Chung, L.-H., Chen, Y.-G., and Wang, Y., 2002, The active tectonics of eastern Taiwan-New insights from the two geomorphic tablelands ("the Feet") in the Longitudinal Valley: Eos (Transactions, American Geophysical Union), v. 83, no. 47, F1281.

Shyu, J.B.H., Sieh, K., Chen, Y.-G., and Liu, C.-S., 2005a, Neotectonic architecture of Taiwan and its implications for future large earthquakes: Journal of Geophysical Research, v. 110, p. B08402, doi: 10.1029/2004JB003251.

Shyu, J.B.H., Sieh, K., and Chen, Y.-G., 2005b, Tandem suturing and disarticulation of the Taiwan orogen revealed by its neotectonic elements: Earth and Planetary Science Letters, v. 233, p. 167-177, doi: 10.1016/ j.eps1.2005.01.018.

Shyu, J.B.H., Sieh, K., Avouac, J.-P., Chen, W.-S., and Chen, Y.-G., 2006a, Millennial slip rate of the Longitudinal Valley fault from river terraces: Implications for convergence across the active suture of eastern Taiwan: Journal of Geophysical Research (in press).

Shyu, J.B.H., Chung, L.-H., Chen, Y.-G., Lee, J.-C., and Sieh, K., 2006b, Re-evaluation of the surface ruptures of the November 1951 earthquake series in eastern Taiwan, and its neotectonic implications: Journal of Asian Earth Sciences (in press).

Stanley, R.S., Hill, L.B., Chang, H.C., and Hu, H.N., 1981, A transect through the metamorphic core of the Central Mountains, southern Taiwan: Geological Society of China Memoir, v. 4, p. 443-473.
Suppe, J., 1981, Mechanics of mountain building and metamorphism in Taiwan: Geological Society of China Memoir, v. 4, p. 67-89.

Teng, L.S., 1987, Stratigraphic records of the late Cenozoic Penglai orogeny of Taiwan: Acta Geologica Taiwanica, v. 25 , p. $205-224$

Teng, L.S., 1990, Late Cenozoic arc-continent collision in Taiwan: Tectonophysics, v. 183, p. 57-76, doi: 10.1016/00401951(90)90188-E

Teng, L.S., 1996, Extensional collapse of the northern Taiwan mountain belt: Geology, v. 24, p. 949-952, doi: 10.1130/ 0091-7613(1996)024<0949:ECOTNT>2.3.CO;2.

Wei, K., Chen, Y.-G., and Liu, T.-K., 1998, Sedimentary history of the Taipei Basin with constraints from thermoluminescence dates: Journal of the Geological Society of China, v. 41, p. 109-125.

Willett, S.D., and Brandon, M.T., 2002, On steady states in mountain belts: Geology, v. 30, p. 175-178, doi: 10.1130/0091-7613(2002)030<0175:OSSIMB > 2.0.CO;2.

Willett, S.D., Beaumont, C., and Fullsack, P., 1993, Mechanica model for the tectonics of doubly vergent compressiona orogens: Geology, v. 21, p. 371-374, doi: 10.1130/00917613(1993)021<0371:MMFTTO>2.3.CO;2.

Willett, S.D., Fisher, D., Fuller, C., Yeh, E.-C., and Lu, C.-Y, 2003, Erosion rates and orogenic-wedge kinematics in Taiwan inferred from fission-track thermochronometry Geology, v. 31, p. 945-948, doi: 10.1130/G19702.1.

Wu, F.T., Chang, C.S., and Wu, Y.M., 2004, Precisely relocated hypocentres, focal mechanisms and active orog eny in Central Taiwan, in Malpas, J., Fletcher, C.J.N., Ali, J.R., and Aitchison, J.C., eds., Aspects of the tectonic evolution of China: Geological Society [London] Special Publication 226, p. 333-354.

Yen, T.P. 1953, On the occurrence of the late Paleozoic fossils in the metamorphic complex of Taiwan: Bulletin of the Geological Survey of Taiwan, v. 4, p. 23-26.

Yen, T.P., Sheng, C.C., and Keng, W.P., 1951, The discovery of fusuline limestone in the metamorphic complex of Taiwan: Bulletin of the Geological Survey of Taiwan, v. 3, p. $23-25$.

Yu, M.-S., 1997, Active faults in the Taitung Longitudinal Valley [Ph.D. thesis]: Taipei, National Taiwan University, $141 \mathrm{p}$.

Yu, S.-B., and Kuo, L.-C., 2001, Present-day crustal motion along the Longitudinal Valley fault, eastern Taiwan: Tectonophysics, v. 333, p. 199-217, doi: 10.1016/ S0040-1951(00)00275-4.

Yu, S.-B., and Liu, C.-C., 1989, Fault creep on the central segment of the Longitudinal Valley fault, eastern Taiwan: Proceedings of the Geological Society of China, v. 32 , p. $209-231$.

Manuscript Received 30 September 2005

ReVised Manuscript ReCEIVEd 17 ApriL 2006

MANUSCRIPT ACCEPTED 30 APRIL 2006

Printed in the USA 